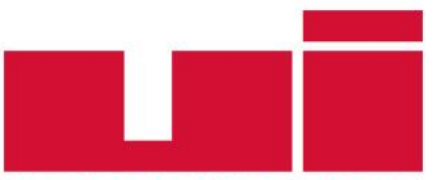

ULUSLARARASIILIȘKiLER

Akademik Dergi

Yayın ilkeleri, izinler ve abonelik hakkında ayrıntılı bilgi:

E-mail: bilgi@uidergisi.com.tr

Web: www.uidergisi.com.tr

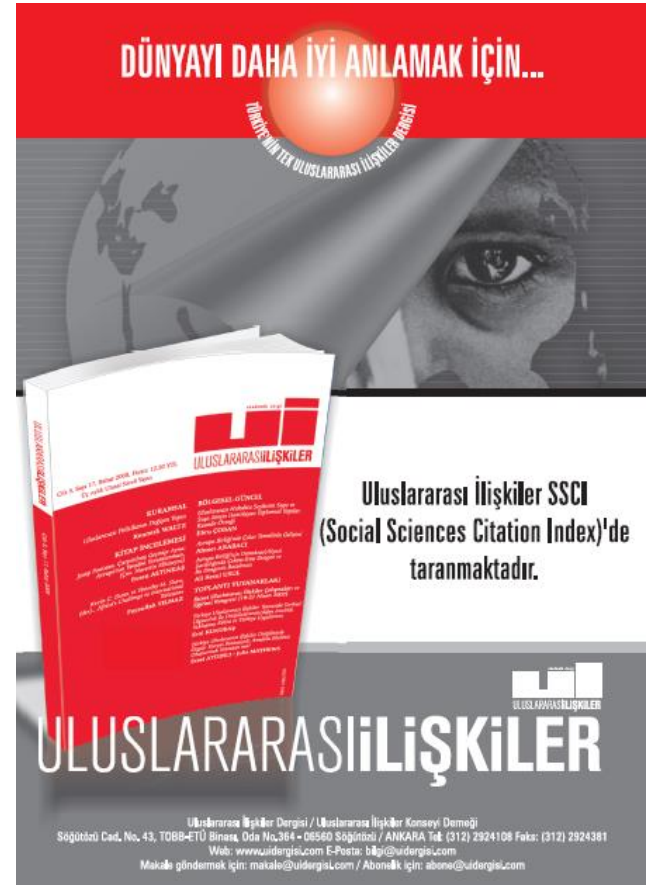

\title{
İdeoloji ve Dış Politika: Türkiye'de Kemalist (1930-1939) ve İslamcı (2011-2015) Dış Politikaların Karşılaştırmalı Bir Analizi
}

\author{
Ramazan KILINÇ* \\ * Doç. Dr., Siyaset Bilimi Bölümü, Nebraska Üniversitesi
}

Bu makaleye atıf için: Kılınç, Ramazan, "İdeoloji ve Dış Politika: Türkiye'de Kemalist (1930-1939) ve İslamcı (20112015) Dış Politikaların Karşılaştırmalı Bir Analizi”, Uluslararası İlişkiler, Cilt 13, Sayı 52, 2016, s. 67-88.

Bu makalenin tüm hakları Uluslararası İlişkiler Konseyi Derneği'ne aittir. Önceden yazılı izin alınmadan hiç bir iletişim, kopyalama ya da yayın sistemi kullanılarak yeniden yayımlanamaz, çoğaltılamaz, dağıtılamaz, satılamaz veya herhangi bir şekilde kamunun ücretli/ücretsiz kullanımına sunulamaz. Akademik ve haber amaçlı kısa alıntılar bu kuralın dışındadır.

Aksi belirtilmediği sürece Uluslararası Illişkiler'de yayınlanan yazılarda belirtilen fikirler yalnızca yazarına/yazarlarına aittir. UİK Derneğini, editörleri ve diğer yazarları bağlamaz. 


\title{
İdeoloji ve Dış Politika: Türkiye’de Kemalist (1930-1939) ve İslamcı (2011-2015) Dış Politikaların Karşılaştırmalı Bir Analizi
}

\author{
Ramazan KILINÇ \\ Doç. Dr., Siyaset Bilimi Bölümü, Nebraska Üniversitesi Omaha Kampüsü ve \\ Eş-Direktör, İslami Çalışmalar Programı.E-posta: rkilinc@unomaha.edu
}

\begin{abstract}
ÖZET
İç politikadaki ideolojik kırılmalar hangi şartlar altında ideoloji temelli dış politika oluşumuna neden olmaktadır? Bu çalışmada 1930-1939 ve 2011-2015 dönemlerindeki Türk dış politikası bu soru etrafında karşısaştırmalı olarak analiz edilmektedir. 1930'lu yıllarda Kemalist elit itidalli ve pragmatik bir dış politika izlerken, 2010’lu yılların ilk yarısında İslamcı elit ideoloji bazlı bir dış politika izlemiştir. Bu farklılı̆̆ açıklamaya çalışan makale, iç siyasette rakipleri tarafından yerinden edilme riski az olan hükümetlerin, uluslararası ortam da kendilerine manevra alanı açıyorsa, iç ideolojik dönüşümlerini dış politikaya yansıtmaya daha eğilimli olduklarını iddia etmektedir.
\end{abstract}

Anahtar Kelimeler: Kemalizm, İslamcılık, Türk Dış Politikası, İdeoloji

\section{Ideology and Foreign Policy: A Comparative Analysis of Kemalist (1930-1939) and Islamist (2011-2015) Foreign Policies in Turkey}

\begin{abstract}
Under what conditions do domestic ideological shifts produce ideology-based foreign policy? In this study, Turkish foreign policies in 1930-1939 and 2011-2015 are comparatively analyzed within the framework of this question. While Kemalist elite pursued a cautious and pragmatic foreign policy in the 1930s, the Islamist elite implemented an ideology-based foreign policy in the first half of the 2010s. This study, which attempts to explain this variation, argues that those governments with low risk of being overthrown in domestic politics tend to pursue an ideologically-induced foreign policy if international environment offers a larger maneuver room to act.
\end{abstract}

Keywords: Kemalism, Islamism, Turkish Foreign Policy, Ideology 


\section{Giriş}

Rusya, 1917 yılında yaşadığı Bolşevik Devrim sonrasında Birinci Dünya Savaşı́ndan çekilmekle kalmamış, savaş sırasında ve sonrasında Batılı güçler tarafından işgal edilen ülkelere bağımsızlık mücadelelerinde önemli destek vermişti. 1979'da gerçekleşen İran Devrimi, ülkedeki 25 yıllık Amerikan-merkezli dış politikayı sona erdirirken, Körfez Arap devletleri için yeni güvenlik tehditlerini de beraberinde getirmişti. Rusya ve İran örneklerinde olduğu gibi ani ve yüksek seviyede gerçekleşen iç politikadaki ideolojik kırılmalar çoğu zaman hızla ve kolaylıkla gözlemlenebilen dış politika değişimlerini de beraberinde getirmektedir. Fakat uzun zamana yayılan ideolojik değişim ve kırılmaların nasıl ve ne zaman dış politika değişikliklerine yol açtığı sorusuna keskin bir cevap bulmak kolay değildir. Bu çalışmada 1930-1939 ve 2011-2015 yıllarındaki Türk dış politikası bu soru çerçevesinde karşılaştırmalı olarak analiz edilecektir.

1930’lu ve 2010'lu yılların hemen öncesinde Türkiye iç politikada köklü değişimler ve ideolojik kırılmalar yaşamıştır. Türkiye 1920'lerde imparatorluktan ulus-devlet düzenine geçmiş, 1930'lara kadar milliyetçilik, Batılılaşma ve laiklik merkezli, kimi araştırmacıların "Kemalizm" olarak adlandırdıkları yeni bir kimliğe bürünmüştür. ${ }^{1} 2000$ 'li yıllarda ise askeri/ sivil bürokrasinin siyaset üzerindeki rolü azalırken, Türkiye’nin İslami kimliğine yapılan vurgular artmıştır. Bu değişimlerin dış politikaya yansımaları kayda değer düzeydedir. 1930'lu yıllarda Türkiye uluslararası sistemde denge siyaseti güderek, artan İtalyan ve Alman tehdidine karşı ittifaklar kurmaya yönelmiş, iç politikada bağımsızlık ve egemenlik gibi değerler vurgulanırken Türkiye yakın çevresinde sömürge idareleri altındaki ülkelerin iç politikalarına karışmama politikasını takip etmiştir. ${ }^{2}$ 2010'lu yılların ilk yarısında ise Türkiye Arap Baharı ile derin bir kriz yaşayan Ortadoğu'da müdahaleci bir dış politika izlemeye yönelmiştir. İç politikada sıkça atıf yapılan İslami kimlik dış politikaya da yansımış, zaman zaman komşu ülkelerin iç işlerine karışma noktasına varan bir yaklaşıma dönüşmüştür. ${ }^{3}$

İç politikadaki ideolojik kırılmalar neden bazen dış politikaya yansırken diğer zamanlarda yansımamaktadır? Türkiye özelinde bu soruya liderlerin karakterlerinden, uluslararası ortamın 1930 ve 2010 ’lu yıllardaki farklılığına, Kemalizm ve İslamcılık ideolojilerinin yerel ya da görece daha evrensel oluşuna, takip edilen elitist ya da popülist dış politika yaklaşımlarına ya da Türkiye'nin her iki dönemdeki siyasi ve ekonomik güç farklılıklarına atıfla farklı cevaplar verilebilir. Bu faktörlerin hepsi şüphesiz ortaya konulan sorunun farklı boyutlarına cevap teşkil edecek açıklamalar sunmaktadır. Ne var ki bu yaklaşımlar çalışmanın sorusuna kapsamlı, tutarlı ve genellenebilir bir açıklama getirmekten yoksundurlar. Bu nedenle elinizdeki çalışma ideolojinin dış politikayı hangi şartlar altında etkilediğine yönelik genel-geçer bir açıklama geliştirmeyi hedeflemektedir. Buna göre ideolojik dönüşüm sonrası iç politikada varlıkları ciddi tehdit altında olmayan, uluslararası ortamda da kendilerini sınırlandırıcı bir dirençle karşılaşmayan hükümetlerin ideolojik dış politika gütme eğilimlerinin daha güçlü olduğu iddia edilmektedir. Başka bir ifadeyle 1930'lar ve 2010'lar Türkiye'sinde iktidarlar içeride kendilerine yönelik güçlü bir tehdit altında değillerken, uluslararası ortam Türkiye'yi 1930'lu yıllarda daha mutedil bir dış politikaya, 2010'lu yılların ilk yarısında ise daha ideolojik ve keskin bir dış politikaya yöneltmiştir. Yönetici elit, 1930’lu yıllarda Türkiye'yi dış tehdit altında algılayıp, bunları dengeleyecek

1 Taha Parla, Ziya Gökalp, Kemalizm ve Türkiye’de Korporatizm, İletişim Yayınları, İstanbul, 1989; Esra Özyürek, Nostalgia for the Modern: State Secularism and Everyday Politics in Turkey, Duke University Press, Durham, NC, 2006.

2 Malik Mufti, Daring and Caution in Turkish Strategic Culture: Republic at Sea, Palgrave Macmillan, London, 2009.

3 Behlül Özkan, “Turkey, Davutoğlu and the Idea of Pan-Islamism”, Survival, Cilt 56 No.4, Temmuz 2014, s.119-140. 
politikalar üretirken, 2010'lu yıllarda Arap Baharı'nın oluşturduğu atmosferde Ortadoğu'da bölgesel liderlik oluşturabileceğine inanmıştır. Sonuçta 1930’larda itidalli, 2010'lu yılların ilk yarısında ise iddialı bir dış politika geliştirilmiştir.

Bu çalışmada ideolojik dış politika kavramı ile ülke yönetiminde hâkim olan ideolojik yaklaşımın dış politika yapımını ne derecede etkilediği kastedilmektedir. Bazı dönemlerde iç politikadaki hâkim ideolojilerin dış politika kararlarının alımında etkisi bulunmazken, diğer dönemlerde bu etki açık şekilde görülmektedir. Birinci durumda karar alıcılar pragmatizme dayalı realist politikalar izlerken, ikinci durumda ideolojik öncelikler pragmatizmin önüne geçebilmektedir. Karar alıcılar, pragmatik dış politikada güç dengelerine ve somut çıkarlara daha fazla önem verirken, ideolojik dış politikada fikirlerden ve dünya görüşünden kaynaklanan değer yargıları daha öne çıkmaktadır. Bu çalışma 19301939 ve 2011-2015 yılları Türk dış politikasını karşılaştırdığı için sırasıyla bu dönemlerin yönetimde hâkim ideolojileri olan Kemalizm ve İslamcılığın dış politikaya etkilerini tartışmaktadır. Tabii ki bu durum diğer ideolojilerin Türk siyasetinde ve dış politika yapımında hiç etkilerinin olmadığı anlamına gelmemektedir.

Çalışmanın geri kalan kısmında öncelikle ideoloji ile dış politika arasındaki ilişkiye yönelik yazın kısaca özetlenerek, çalışmanın teorik çerçevesi ortaya konulacaktır. Daha sonra 1930-1939 ve 2011-2015 dönemlerinde yürütülen Türk dış politikası bu çerçevede karşılaştırmalı olarak analiz edilecektir. Bu analiz ile iç siyaset-uluslararası ortam etkileşiminin, ideoloji-dış politika yapımı ilişkisini nasıl etkilediği gösterilecektir.

\section{İdeoloji ve Dış Politika}

İdeolojiyi kısaca her hangi bir düşünce sistemine göre ideal toplum için gerekli görülen normatif değerler ve inançlar sistemi olarak tanımlayabiliriz. ${ }^{4}$ Dış politikaya etkisi uzun zamandır tartışılagelen ideolojilerin, ${ }^{5}$ dış politika yapımında etkilerinin olmadığını iddia edenler ${ }^{6}$ ile dış politika yapım sürecinin önemli bir faktörü olduğunu savunanların yanı sıra, ${ }^{7}$ bu iki fikre de katılmayıp, ideolojilerin diğer faktörler ile birlikte dış politika yapımında etkili olduğunu savunan araştırmacılar da vardır.

Özellikle Waltz ve Mearsheimer gibi dış politikada güç ve ulusal çıkarları vurgulayan yapısalcı realist okula sahip olan uzmanlar ile Nye ve Moravcsik gibi ulusal çıarların ve bunların ürünü olan uluslararası kurumların dış siyasetteki önemine vurgu yapan uzmanlar, ideolojilerin dış politika yapımında etkisiz olduklarını iddia ederler. ${ }^{8}$ Bu yaklaşıma göre ideolojilerin dış politika analizlerinde önemi bulunmamaktadır.

4 Werner Levi, “Ideology, Interests, and Foreign Policy”, International Studies Quarterly, Cilt 14 No.1, 1970, s.4.

5 Ibid.; Michael Hunt, Ideology and U.S. Foreign Policy, Yale University Press, New Haven, 2009; Judith Goldstein and Robert O. Keohane, Ideas and Foreign Policy: Beliefs, Institutions, and Political Change, Cornell University Press, Ithaca, 1993; Michael Barnett, "Culture, Strategy and Foreign Policy Change: Israel's Road to Oslo", European Journal of International Relations, Cilt 5 No.1, 1999, s.5-36; Karl J. Holsti, "National Role Conceptions in the Study of Foreign Policy”, International Studies Quarterly, Cilt 14 No.3 1970, s.233-309.

6 Kenneth Waltz, Theory of International Politics, McGraw Hill, New York, 1979.

7 Hunt, Ideology and U.S. Foreign Policy.

8 Waltz, Theory of International Politics; John J. Mearsheimer, The Tragedy of Great Power Politics, Norton, New York, 2001; Joseph S. Nye, "Redefining the National Interest", Foreign Affairs, Cilt 78 No.4, 1999, s.22-35; Andrew Moravcsik, "A New Statecraft? Supranational Entrepreneurs and International Cooperation”, International Organization, Cilt 53 No.2, 1999, s.267-306. 
$\mathrm{Bu}$ fikrin tersine, Hunt gibi bazı uzmanlar ideolojilerin dış politika yapımında en önemli parametre olduğunu savunmaktadırlar. Mesela, dış politika analizlerinde fikirlerin rolünün ihmal edilmesini eleştirerek yola çıkan Hunt, Amerikan dış politikasındaki değişimlerin tamamen iç siyasetteki ideolojik değişimlerin ürünü olduğunu yazmaktadır. ${ }^{9}$ Fikirlerin uluslararası ilişkilerde önemine vurgu yapan inşacılara göre ise ideolojiler materyal faktörlerle etkileşim halinde dış politika yapımına katkıda bulunurlar. ${ }^{10}$ Mesela Barnett, 1990'lı yıllarda İsrail'in Oslo Barış sürecine yönelik dış politikasında iç siyasetteki stratejik faktörlerin yanı sıra ideolojik dönüşümlerin de önemli bir rol oynadığı kanısındadır. ${ }^{11}$

Diğer yandan ideolojilerin dış politika yapımında etkili olduğunu ancak etkilerinin çok sınırlı olduğunu savunan uzmanlar da bulunmaktadır. Örneğin Werner Levi, ideolojilerin karar alma aşamasında çok etkili olmasa da, devletlerin aldıkları kararları meşrulaştırmada sıkça kullandıkları bir enstrüman olduğunu iddia etmektedir. ${ }^{12}$ Karl Holsti ise devletlerin dış politikada kendilerine ideolojilerinin de etkisiyle bir ulusal rol biçtiklerini ve bu rolün dış politika yapım sürecinde karar alıcılar üzerinde kilit rol oynadığını yazmaktadır. ${ }^{13}$ Judith Goldstein ve Robert O. Keohane, ideolojilerin dış politikayı stratejik bir dengenin olmadığı zamanlarda veya ideolojilerin kurumlara eklemlendiği durumlarda etkilediklerini savunmuşlardır. ${ }^{14}$

$\mathrm{Bu}$ çalışmanın odaklandığı soruya verilecek cevap için de yazında birçok yaklaşıma rastlamak mümkündür. Kemalist ideolojik dönüşümün 1930’larda itidalli dış politika üretirken, İslamcı dönüşümün 2010'lu yılların ilk yarısında neden ideolojik temelli dış politika ürettiğine yönelik muhtemel açılamalardan birisi Kemalizm ve İslamcılık ideolojilerinin doğalarındaki farklılıktır. Her ne kadar, milliyetçi bir proje olarak Kemalizm'in diş politikada müdahaleci sonuçlar üretmesi mümkündüyse de ${ }^{15}$ görece daha az ülke sınırlarıyla tanımlanan ve özünde Müslümanların birliği temelinde ümmetçiliğe dayanan İslamcılığın maceracı bir dış politika üretme potansiyelinin daha yüksek olduğu iddia edilebilir. Pratikte Kemalizm sömürgeci devletler tarafından işgal edilen "mazlum milletlere" ilham olmayı hedeflerken, ${ }^{16}$ Türkiye'deki İslamcılık büyük ölçüde milliyetçilik ile yoğrularak gelişmiş ve hedefleri yakın döneme kadar büyük ölçüde ülkesel kalmıştır. ${ }^{17}$

1930'lu yıllar ile 2010'lu yılların ilk yarısındaki ideolojik olarak farklı dış politika yönelimlerine o dönemdeki liderlerin farklı kişilik özellikleri de başka bir açıklama olabilir. Cumhuriyetin kurucusu olan Mustafa Kemal Atatürk, bir son dönem Osmanlı paşası olarak, imparatorluğun yıkımına şahit olmuş, Kurtuluş Savaşı́na önderlik etmiş ve yeni bir devletin kurulmasına ön ayak olmuştur. Bu yıkımların arkasından, üstelik içerde radikal bir modernleşme süreci yaşayan ülkesinin maceracı dış

9 Hunt, Ideology and U.S. Foreign Policy.

10 Alexander Wendt, Social Theory of International Politics, Cambridge University Press, New York, 1999; Nicholas Onuf, "Institutions, Intentions, and International Relations", Review of International Studies, Cilt 28 No.2, 2002, s.211-228; Barnett, "Culture, Strategy and Foreign Policy Change”.

11 Barnett, "Culture, Strategy and Foreign Policy ChangeA. L. Macfie, , Turkish Foreign Policy During the Second World War: Active Neutrality, New York, Cambridge University Press, ly”.

12 Levi, "Ideology, Interests, and Foreign Policy", s.5.

13 Holsti, "National Role Conceptions in the Study of Foreign Policy".

14 Judith Goldstein ve Robert O. Keohane, "Ideas and Foreign Policy: An Analytical Framework”, Judith Goldstein ve Robert O. Keohane (der), Ideas and Foreign Policy: Beliefs, Institutions, and Political Change, Cornell University Press, Ithaca, 1993, s.3.

15 Örneğin Almanya ve İtalyan örneklerinde milliyetçi ideolojilere dayalı birçok projeler zamanla irredantizme yönelmişlerdir.

16 Orhan Koloğlu, Mazlum Milletler Devrimleri ve Türk Devrimi, 2. Baskı, Kaynak Yayınları, Ankara, 2004.

17 Tanıl Bora, Türk Sağının Üç Hali, İletişim, İstanbul, 1998. 
politikaya sürüklenmesini istememiş olması muhtemeldir. ${ }^{18}$ Bu nedenle itidalli bir dış politika izlemiş olması anlaşılabilir. Diğer yandan, 2000'li yıllarda iktidarda bulunan Adalet ve Kalkınma Partisi'nin (AKP) lideri Recep Tayyip Erdoğan'ın ise, dünyayı doğru/yanlış, haklı/haksız, suçlu/masum gibi ikici (dualist) kategorilerle algılayan yaklaşımının, daha keskin bir politikayı doğurduğu iddia edilebilir. ${ }^{19}$ Fakat bu yaklaşım da problemlidir. Zira, Atatürk Hatay'ın Türkiye topraklarına ilhakında olduğu gibi gerektiği zaman riskli politikalara girmekten çekinmezken, ${ }^{20}$ Erdoğan da AKP iktidarının ilk iki döneminde pragmatik ve nüanslara dikkat eden politikalar izlemiştir. ${ }^{21}$

Başka bir yaklaşım Türkiye'nin 1930 'lu ve 2010 'lu yıllardaki farklı dış politika tercihlerini uluslararası sistemdekiyerine bakarak açıklamak olabilir. ${ }^{22}$ Buna göre Türkiye'nin 2000'li yıllar boyunca gerçekleştirdiği ekonomik kalkınmanın bölgesindeki ağırlığını artırdığı ve dış politikada risk alabilen yaklaşımın da bunun bir sonucu olduğu iddia edilebilir. ${ }^{23}$ Buna karşlık henüz savaştan yeni çıkmış 1930’lar Türkiye'sinin risk alabilen bir siyaseti takip etmesi beklenemezdi. Fakat bazı akademisyenler Türkiye'nin Cumhuriyet'in ilk yıllarında da orta ölçekli bir güç olarak kimi kararların alınmasında etkili olabilen önemli bir uluslararası aktör olduğunu göstermişlerdir. ${ }^{24}$ Nitekim Türkiye'nin 1930’lu yıllarda yükselen İtalyan ve Alman tehditlerine karşı bölgesel ittifaklar oluşturmakta başarılı olduğu ortadadır.

1930’lu yıllar ve 2010'lu yılların ilk yarısındaki politika farklılıklarını anlamamıza yardımcı olacak başka bir açıklama Kemalizm’in daha elitist, İslamcıllğın ise daha popülist bir sosyal tabana dayanıyor olması olabilir. Kemalist elit rekabetçi seçimlerle işbaşına gelmemiş, yukarıdan reformcu programını uygulamak için popüler meşruiyete ihtiyaç duymamıştır. İslamcı ideolojinin iktidarını mümkün kılan ise seçimlerle gelen popüler destek olmuştur. Bu yaklaşıma göre AKP'nin iç politikada üstünlük kazanmak ve İslamcı tabanını tatmin etmek için daha ideoloji temelli dış politika yürüttügü söylenebilir. Fakat AKP'nin Türkiye'deki siyasal hâkimiyetini kurduktan sonra ve büyük ölçüde 2011-2015 arası dönemde ideolojik eksende dış politika takip ettiği göz önünde bulundurulursa, bu açıllama da tatmin edici olmaktan çıkar.

Şüphesiz Kemalizm ve İslamcılık arasındaki farklılıklar, Atatürk ve Erdoğan’ın farklı kişilikleri, Türkiye'nin uluslararası sistemdeki yeri ile elitist ve popülist yaklaşım farklılıkları gibi etmenler ideolojinin ne zaman dış politikayı etkileyeceğini kısmen açıklar. Ne var ki sistemli bir açıklamanın iç siyaset ve uluslararası ortamı birlikte dikkate alan analitik bir çerçeveye ihtiyacı vardır. Bu tür bir yaklaşımdan yola çıkan bu çalışma, ideoloji merkezli dış politika oluşumunu iç siyaset ve uluslararası ortamın karşılıklı etkileşimine bağlamaktadır. Buna göre, ideolojinin pragmatizmin önüne geçmesi için hem iç politikada, hem de uluslararası sistemde karar alıcıları dengeleyici faktörlerin azalması gerekir. İç siyasette rakiplerinin kendisini alt etme tehdidi altında olan iktidarların ideoloji eksenli

18 Nimet Arsan (der.), Atatürk'ün Söylev ve Demeçleri, Türk İnkılap Tarihi Enstitüsü, Ankara, 1961, s.201; Frederick W. Frey, The Turkish Political Elite, MIT Press, Boston, MA, 1965.

19 Aylin Ş. Görener ve Meltem Ş. Ucar, “The Personality and Leadership Style of Recep Tayyip Erdoğan: Implications for Turkish Foreign Policy”, Turkish Studies, Cilt 12 No.3, 2011, s.357-81.

20 Ercan Karakoç, "Atatürk’ün Hatay Davası", Bilig, Sayı 50, 2009, s.97-118.

21 Ziya Öniş ve Şuhnaz Yılmaz, "Between Europeanization and Euro-Asianism: Foreign Policy Activism in Turkey during the AKP Era”, Turkish Studies, Cilt 10 Sayı 1, 2009, s.7-24.

22 Soner Çagaptay, “Defining Turkish Power: Turkey as a Rising Power Embedded in the Western International System”, Turkish Studies, Cilt 14 No.4, 2013, s.797-811.

23 Kemal Kirişçi, “The Transformation of Turkish Foreign Policy: The Rise of the Trading State”, New Perspectives on Turkey, Say1 40, 2009, s.29-57.

24 Dilek Barlas, "Turkish Diplomacy in the Balkans and the Mediterranean: Opportunities and Limits for Middle-Power Activism in the 1930s", Journal of Contemporary History, Cilt 40 No.3, 2005, s.441-464. 
dış politika yürütme ihtimalleri düşüktür. ${ }^{25}$ Benzer şekilde, sınırlayıcı ve dengeleyici bir uluslararası ortam da, iktidarların ideoloji eksenli dış politika geliştirme olasılığını düşürür. ${ }^{26}$ İç siyasi dengeler ve uluslararası ortamın durumunun farklı kombinasyonları sonucu ortaya çıkabilecek dört farklı dış politika sonucu Tablo 1'de verilmiştir.

Tablo 1. İç Siyaset ve Uluslararası Ortamın İdeoloji Bazlı Dış Politika Oluşumuna Etkisi

\begin{tabular}{lccc}
\hline & \multicolumn{2}{c}{ Uluslararası Ortam } \\
\cline { 2 - 4 } & Sınırlayıcı & Sınırlayııı Olmayan \\
\hline \multirow{4}{*}{ İç Siyaset } & $\begin{array}{c}\text { (1) Statüko Bazlı Dış Politika } \\
\text { 1920'li yıllar Türk dış politikası ile } \\
\text { 2002-2007 Türk dış politikası }\end{array}$ & $\begin{array}{c}\text { (3) Dış Politika Aktivizmi } \\
1990 \text { 'lı yıllar Türk dış politikası }\end{array}$ \\
\cline { 2 - 4 } & $\begin{array}{c}\text { (2) Dış Politika Aktivizmi } \\
\text { Sınırlayıcı } \\
\text { Olmayan }\end{array}$ & $\begin{array}{c}\text { 1930'lu yıllar Türk dış politikası ile } \\
\text { 2007-2011 Türk dış politikası }\end{array}$ & $\begin{array}{c}\text { (4) İdeoloji Bazlı Dış Politika } \\
\text { 2011-2015 arası Türk dış politikası }\end{array}$ \\
\hline
\end{tabular}

Buna göre, hem iç siyaset hem de uluslararası ortam tarafından sınırlandırılmış iktidarlar statüko merkezli bir dış politikayı tercih ederler. Zira var olma mücadelesi veren bu tür iktidarlar, ideoloji temelli riskli politikalar geliştirmekten kaçınırlar ve dış politikalarında hem iç siyasetin hem de uluslararası toplumun çizgisi dışına çıkmamayı yeğlerler. Bu durum ideoloji eksenli bir dış politika takip edilmesi ihtimalinin en düşük olduğu durumdur. Bu dönemde iktidarda olanlar ülkelerinin daha önce belirlenmiş dış politika çizgisinin dışına çıkmaktan ve uluslararası güç merkezlerini rahatsız edecek bir siyaset takip etmekten sakınırlar. Türkiye'nin 1920'li yıllardaki dış politikası ya da AKP'nin 2002-2007 yılları arasındaki dış politikası bu kategoriye örnek olarak verilebilir. Her iki durumda da siyasi elit hem iç siyasette rakipleri tarafından yerlerinden edilme tehlikesi ile hem de uluslararası sistemin bıraktığı dar bir alanda hareket etmişlerdir. 1920'li yıllarda Cumhuriyet' in kurucu eliti yeni bir ulus-devlet projesini devreye sokarken iç siyasette tam hâkimiyet kurmakla meşgul olmuş, dış siyasette ise yeni kurulan devletin uluslararası toplum tarafından tanınması ve sınırlarının güvenliği meselesi ile ilgilenmiştir. Yeni devletin kuruluşunun zamanın önemli Avrupa devletlerine karşı kazanılan askeri zaferlerden sonra gerçekleştirilmiş olması dikkatli bir uluslararası siyaseti de gerekli kılmıştır. Kurucu elit uluslararası güç odaklarını tahrik edecek politikalardan uzak durmuştur. AKP iktidarının ilk dönemi de benzer bir siyasi ortama tekabül etmektedir. 28 Şubat sürecinden hemen sonra iktidara gelen AKP, iç siyasette askeri vesayetin gölgesi altında hareket etmek zorunda kalmış, dış siyasette de 11 Eylül sonrası bulunduğu bölgede aktif varlık gösteren ABD’nin ulusal güvenlik stratejileri ile sınırlandırılmıştır. Bu durumda AKP, Türkiye’nin geleneksel olarak en önemli dış politika öncelikleri arasında görülen $A B$ üyeliği ve Batı-merkezciliği esas almış, hem içeride hem de dışarıda statüko ile uyumlu bir çizgide hareket ederek, siyasi varlığını tehlikeye atacak çıkışlardan kaçınmıştır.

Uluslararası ortam tarafından dengelenen fakat iç siyasette varlığına güçlü bir tehditle karşılaşmayan iktidarlar ise pragmatizme dayalı aktif bir dış politika yürütürler. İç politikada belli bir güce erişmiş olan bu iktidarlar, ideolojilerine uygun politikayı yürütecek uluslararası ortam olmadığından uluslararası statükoyu dikkate alan, fakat aktif bir dış politika izlerler. Bu politika sayesinde uluslararası meşruiyetlerini ve ittifaklarını canlı tutmayı amaçlarlar. 1930'lu yıllar Türk dış

25 Jack Snyder, Myths of Empire: Domestic Politics and International Ambition, Cornell University Press, Ithaca, NY, 1991.

26 Mohammed Ayoob, Third World Security Predicament: State-Making, Regional Conflict and the International System, Lynne Rienner, Boulder, CO, 1995. 
politikası ya da 2007-2011 yılları arası Türk dış politikası bu kategori için güzel örneklerdir. Her iki zaman diliminde de karar alıcılar iç siyasette güçlerini artırıp iktidara yönelik tehditleri yok etmişler, fakat ideolojilerine uygun dış politika oluşturacak uluslararası manevra alanından yoksun kalmışlardır. $\mathrm{Bu}$ yüzden de iktidarlarının uluslararası toplum tarafından meşruiyetini artırıcı, mevcut uluslararası sistemi tehdit etmeyen, fakat aktif bir dış politika takip etmişlerdir. 1930'lu yıllarda kurucu elitin ulusdevlet projesi ikame edilmiş, karar alıcılar iç siyasetteki rakiplerin sisteme karşı tehditlerini minimize ederken, dış siyasette de uluslararası toplumla uyum içinde artan İtalyan, Alman ve 1930'lu yılların sonuna doğru da Sovyet tehdidine karşı ittifaklar kurmakla meşgul olmuşlardır. Bu dönemde Türkiye Balkanlar, Ortadoğu ve Akdeniz de güvenliğini garantiye alacak ittifaklar kurulması için aktif bir dış politika izlemiş, kısa sürede Avrupa diplomasisinin önemsenen bir aktörü olmayı başarmıştır. Benzer şekilde, 2007-2011 yılları arasında da AKP büyük oranda kendi iktidarını sınırlandıran askeri vesayetten kurtularak iç siyasette elini güçlendirmiş, dış siyasette ise Arap Baharına kadar Ortadoğu'daki güçlü varlığını sürdüren ABD’yi tahrik etmeden Avrupa, Balkanlar, Ortadoğu ve Kafkaslarda aktif bir dış politika izlemiştir. Türkiye bu dış politika aktivizmi sayesinde bölgesindeki çatışmalarda arabuluculuk yapabilmiş, çeşitli ülkelerle ticaret ve esnek vize anlaşmaları imzalamıştır. İç politikada elini güçlendirmesi AKP'yi daha aktif bir politikaya yönlendirmiş fakat uluslararası ortamdaki manevra alanının darlı̆̆ı riskli ve uluslararası statükoyu rahatsız edecek politikalardan uzak kalmaya zorlamıstır.

Tabloda üçüncü alternatif olarak belirtildiği üzere, uluslararası ortam tarafından sınırlanmayan fakat iç siyasette gücü tehdit altında bulunan iktidarlar pragmatizme dayalı aktif dış politika yürütebilirler. ${ }^{27} \mathrm{Bu}$ şartlar altındaki iktidarlar dış politika aktivizmi sayesinde iç siyasette güç ve meşruiyet kazanmaya çalışırlar. Fakat iç siyasetteki güçlerini riske atmamak için de, aktif dış politikalarında statükonun çizdiği sınırların dışına çıkmamaya gayret ederler. Burada statükonun ne olduğunu büyük ölçüde iç siyasetin gerekleri belirler. Diğer bir ifadeyle, ülkenin sahip olduğu geleneksel dış politika çizgisi belirleyicidir. Türkiye'nin 1990’lı yıllardaki dış politikası bu kategoriye örnek olarak verilebilir. Bu yıllarda Sovyetler Birliği’nin dağılması ile birlikte Soğuk Savaş’ın iki kutuplu dünyası sona ermiş, uluslararası sistemde yeni manevra alanları açılmıştır. Bu dönemde önce Anavatan Partisi, sonra da koalisyonlardan oluşan iktidarlar bir yandan bu yeni sistemde aktif bir diş politikayla kazanç elde etmeye çalışırken, diğer yandan iç politikanın önemli belirleyicilerinden olan ordunun vesayeti ile sınırlandırılmışlardır. Ordunun etkisi bu dönemdeki dış politika aktivizminin sınırlarını belirlemiş, geleneksel dış politika çizgisinin dışına çıkılacak adımlardan kaçınılmışıı. $\mathrm{Bu}$ yöndeki özellikle Refah Partisi ve Doğru Yol Partisi koalisyonu sırasında karşımıza çıkan revizyonist girişimler ordunun müdahalesi ile akamete uğramıştır.

Son olarak, iç siyasette iktidarları rakipleri tarafından tehdit altında olmayan, uluslararası ortam tarafından da sınırlanmayan karar alıcıların ideoloji merkezli dış politika geliştirme eğilimleri daha güçlüdür. Türkiye'nin 2011-2015 arası dış politikası bu kategoriye örnek olarak verilebilir. Bu dönemde AKP, iç siyasette ordunun vesayetinden kurtulmakla kalmamış, siyasi gücünü sağlamlaştırmayı da başarmıştır. Askeri vesayetin sona erdiği, siyasetçilerin sistem üzerinde kontrol sağladığı ve demokratik çoğulculuk beklentilerinin arttığı bu dönemde iktidar İslamcılık ideolojisini öne çıkarmış, iç politikada çoğulcu yerine çoğunlukçu popülist bir anlayışa geçerken, dış politikada da Sünni İslamcı refleksleri

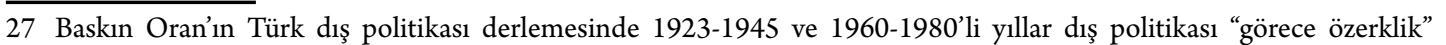
dönemleri olarak tanımlanmıştır. Bu tanım burada geliştirilen tipoloji ile benzerlik göstermektedir. Ancak Oran bu tanımlamayı yaparken daha ziyade uluslararası dinamikleri göz önünde bulundurmaktadır. Baskın Oran, Türk Dış Politikası: Kurtuluş Savaşından Bugüne Olgular, Belgeler, Yorumlar, Cilt 1: 1919-1980, İletişim Yayınları, İstanbul, 2001. 
yüksek bir noktaya evrilmiştir. Bu dönüşümü mümkün kılan ise değişen uluslararası dengeler ve bölgesel dinamiklerdir. Aynı dönemde ABD, Arap Baharı sonrası Ortadoğu'daki politikalarında göreceli olarak daha az müdahaleci bir siyaseti tercih etmiştir. Özellikle aşırı radikal grupların Ortadoğu'da yükselmesi ile birlikte $\mathrm{ABD}$, müttefikleri ile münasebetlerini bozmamak adına onların müdahaleci politikalarına müsamaha ile yaklaşmıştır. AB’nin de Arap Baharı sonrası oluşan mülteci krizinde Türkiye'nin işbirliğine ihtiyaç duyması, hükümetin manevra alanını genişletmiş, uluslararası sistemin sınırlayıcılığını azaltmıştır.

Çalışmanın ilerleyen bölümlerinde burada ortaya konulan tipoloji çerçevesinde neden 1930’larda itidalli, fakat 2011-2015 arasında müdahaleci bir dış politika takip edildiği ayrıntılı şekilde ele alınacaktır.

\section{0’lu Yıllar Türk Dış Politikası}

1930’lu yıllarda Kemalist elit Türkiye’de siyasal egemenliğini inşa etmiş, iç politikada ideolojik önceliklerini hayata geçirecek politikalar uygulamıştır. Ne var ki yükselen İtalyan ve Alman tehdidi hükümeti dış politikada itidalli davranmaya itmiş, pragmatik ittifak arayışları bu dönemin tanımlayıcı özelliği olmuştur. Bu dönem, iç siyasette güçlü aktörlerin ideolojik yaklaşımlarını dış politikaya aktarabilmelerinin uluslararası ortam tarafından nasıl sınırlandırılabileceğini gösteren güzel bir örnektir.

1923'de cumhuriyetin ilanı ile Türkiye'de yeni bir dönem başlamıştır. Yeni Türkiye, eski monarşi rejiminden kendini kalın çizgilerle ayırırken, "çağdaş uygarlık seviyesi” olarak adlandırdığı Avrupa ülkelerinin siyasi ve kültürel değerlerine ulaşmayı hedef olarak seçmiştir. 1920'li yıllar Türkiye'de köklü değişimlerin yaşandığı, ekonomik, siyasi ve sosyal hayatta reformların hayata geçirildiği yıllar olmuştur. Ülkeyi yöneten siyasi kadro, bilinçli bir şekilde Osmanl-İ́slam geleneği ile arasına mesafe koyarken, bunu laik ve ulusalıı bir kültürle ikame etmeye çalışmışır. Mufti’nin de belirttiği gibi, yeni elitler imparatorluk geleneğini, hem toplumda daha homojen bir millet tahayyülü ile hem de İmparatorluğu kurtarmak için ortaya atılan Osmanlıcı, İslamcı ve Turancı gibi genişlemeci ideolojilerle arasına mesafe koyarak terk etmiştir. ${ }^{28}$

Kurucu elit coğrafi olarak Misak-ı Milli ile tanımlanan sınırlar içerisinde, ulusalcı, laik ve modern bir ulus-devlet projesi kurgulamıştır. Bu yönüyle Cumhuriyet Batıcı bir projedir. Ne var ki, Türkiye bağımsızlığını da Batılı devletlere karşı mücadele ile kazandığından, yeni elitler siyasi olarak Batı ile de aralarına mesafe koymuşlardır. Cumhuriyet her şeyden önce bir ulus-devlet projesidir ve tam da bu yüzden bu projenin birincil ayağı milliyetçiliktir. Kemalist elit Batı dünyasında siyasi ve ekonomik açıdan kabul görecek modern bir ulus-devlet oluşturmak istemiştir. Türk ulusal kimliği ortak payda olarak belirlenmiş, etnik farklılıklara hoşgörü ile bakılmamış, homojen bir millet tahayyül edilmiştir. Bağımsızlık, egemenlik ve yeni çizilen sınırların güvenliği bu milliyetçi bakışın temel parametreleri olmuştur.

Kemalist ulus-devlet projesinin ikinci önemli ayağı ise laikliktir. Kurucu elit her ne kadar kimlik olarak Türk milliyetçiliğini Sünni Müslümanlıkla ilişkilendirmişse de, devlet yönetiminde dinin etkisini azaltmayı hedeflemiştir. Kemalist elit bununla kalmamış, laikliği kültürel politikalara da kaydırmış ve geniş çaplı bir laikleştirme siyaseti takip etmiştir. Bu siyasetin gereği olarak 1920'li yıllarda halifelik kaldırılmış, din işleri ile ilgili bakanlıklar lağvedilmiş, dini vakıfların mallarına el

28 Mufti, Daring and Caution in Turkish Strategic Culture, s.18. 
konulmuş, dini mahkemelere son verilmiş, medeni hukuk Batılı devletler örnek alınarak laikleştirilmiş, Arap alfabesi yerine Latin alfabesi kabul edilmiş, tekke ve zaviyeler yasaklanmış ve dini kıyafetlerin kamusal alanda kullanılmasına sınırlandırmalar getirilmiştir. Bu reformlar sayesinde hem Osmanlıİslam geleneğinden uzaklaşılmış hem de yeni kurulan ulus-devlet için yeni kimlik arayışına kısa vadeli bir çözüm üretilmiştir. ${ }^{29}$

Ulus-devlet projesinin üçüncü önemli ayağı ise Batılılaşma temelli modernleşmedir. Her ne kadar Türkiye Cumhuriyeti Batı ile girişilen savaşlarda kazanılan zaferlerle Batılı devletlere karşı kurulmuşsa da kurucu kadro Batının Aydınlanma felsefesinden etkilenmiş son Osmanlı elitlerinden oluşmaktaydı. Bu nedenle Osmanlı İmparatorluğu'nda Tanzimat'la başlayan Batılılaşma arayışları Cumhuriyetin kurulması ile zirve noktasına ulaşmış, siyasi, ekonomik ve kültürel alanlarda yapılan reformlarla hızlı bir Batılılaşma sürecine girilmiştir. Kemalist elit, standardını Avrupa olarak belirlediği "muasır medeniyetler seviyesine" ulaşmayı milli hedef haline getirmiştir. Hukuki ve siyasi kurumlardan resmi tatil günlerine, ölçü birimlerinden kılık ve kıyafet düzenlemelerine, kültürel faaliyet alanlarından sanat pratiklerine kadar bir dizi reform ile geniş çaplı bir modernleşme süreci izlenmiştir. ${ }^{30}$ Böylece 1930’lu yıllara gelindiğinde Türkiye cumhuriyeti milliyetçilik, laiklik ve modernleşme ekseninde yeni bir ulus-devlet olma yolunda önemli bir mesafe kaydetmiştir.

1920’li yıllar ulus-devletin konsolidasyonu çabaları ile geçmiştir. Bu süreçte Kemalist elit yeni ulus-devlete karşı girişilen isyanları ve muhalif hareketliliği kendi gücünü sağlamlaştırmak için araçsallaştırmıştır. Örneğin 1925 Şeyh Sait İsyanı Kemalist elite kendi gücünü ikame edecek yeni kanunlar çıkarma firsatı vermiştir. Takriri Sükûn Kanunu ile devlete muhalif görülen grupların tasfiye edilebilmesi mümkün hale gelmiştir. Kemalist elit, 1924 ve 1930'da kısa süreliğine muhalif partilerin kurulmasına izin vermiş olsa bile, bu partilerin aktif siyasette kalmasına izin vermemiş, tek parti rejimini güçlendirerek ülke üzerinde mutlak hâkimiyetini kurmuştur. 1930'ların başına gelindiğinde Türkiye, muhaliflerini etkisiz hale getirmiş tipik bir parti devleti hüviyeti kazanmışt. Bazı araştırmacılar 1930'lu yıllarda Kemalizm'in devletçi, sosyalist ve liberal yorumlarının çatışma halinde olduğunu yazsalar da, devletçi yorumun rakiplerini alt ederek siyasi üstünlüğü ele geçirdiğini söylemek yerinde bir tespit olacaktır. ${ }^{31}$ Diğer yorumlar küçük entelektüel gruplar halinde kalmışlar, siyasi gücü ele geçirememişlerdir. Kemalizm dışındaki diğer ideolojiler ise bu dönem siyasetinde tamamen etkilerini kaybetmişlerdir. ${ }^{32}$

İç siyasette yaşanan bu köklü değişimler, hiç şüphesiz Türk dış politikasını da etkilemiştir. Kurucu devlet ideolojisi ile ilk dönem dış politikasının ilişkili olduğunu savunan araştırmacılardan Aydın, Atatürk’ün dış politika teori ve pratiğinin Türk dış politikasını şekillendiren en önemli faktör olduğunu iddia etmektedir. ${ }^{33}$ Aydın’a göre Kemalist dış siyaset üç ilkeye dayanmaktadır: "Türk milliyetçiliği ile şekillenmiş tam bağımsız bir ulusal devletin kurulması ve korunması; Kemalist ilkeler vesilesi ile Türkiye’nin muasır medeniyetler seviyesine ulaştırılması ve dış politika yapımında gerçekçi

29 Ahmet T. Kuru, Secularism and State Policies toward Religion: The United States, France, and Turkey, Cambridge University Press, New York, 2009, s.202-235.

30 Hale Yllmaz, Becoming Turkish: Nationalist Reforms and Cultural Negotiations in Early Republican Turkey, 1923-1945, Syracuse University Press, Syracuse, 2013.

31 Hasan Kösebalaban, Turkish Foreign Policy: Islam, Nationalism, and Globalization, Palgrave Macmillan, New York, 2011, s.47-68

32 Bu dönem ideolojilerini ve siyaseti üzerine bir araştırma için bkz. Evren Altınkaş, “Cumhuriyet’in İlk Yıllarında Aydınlar: Kurucu İdeolojinin Seçkinleri”, Cumhuriyet Tarihi Araştırmaları Dergisi, Cilt 7 No.4, 201 1, s.114-132.

33 Mustafa Aydın, "Determinants of Turkish Foreign Policy: Historical Framework and Traditional Inputs", Middle Eastern Studies, Cilt 35 No.4, 1999, s.170. 
ve barışçıl araçlara bağlı kalınması.”34 Aydın, bu ilkelerin gereği olarak Kemalist elitin, emperyal anlamlar içeren Osmanlıcılık, pan-İslamizm ve pan-Turanizm ile arasına kalın bir çizgi çektiğini, bunların yerini Cumhuriyetçilik, Laiklik ve Milliyetçilik ilkelerinin aldığını belirtir. ${ }^{35}$

1920’li ve 1930’lu yıllar Türk dış politikasının kısa bir değerlendirmesi Aydın’ın tespitlerinin haklılığını gösterir. Gerçekten de bağımsızlık ve Batılılaşma ile gerçekçi ve barışçıl bir yaklaşım bu dönemdeki dış politikanın önemli unsurları olmuştur. İmparatorluk mirası üzerine kurulu yeni bir ulusdevlet projesinin hayata geçirilmesi uluslararası tanınırlık ve meşruiyeti ön plana çıartmış, barışçıl bir dış politika takip edilmesini gerekli kılmıştır. Bu noktadan bakıldığında Kemalist dış politika özünde itidalli olmayı da beraberinde getirir. Fakat Kemalist ulus-devlet projesi dikkatli incelendiğinde bu ilkelere ilaveten Kemalist dış politika doktrininde güçlü bir anti-emperyalizm söyleminin olması da beklenir. Zira cumhuriyetin kurulması için Batı emperyalizmine karşı verilen mücadeleye ve iç siyasette ulusal egemenliğe atfedilen öneme bakarak Kemalist elitten kolonyal idare altında yaşayan Ortadoğu, Afrika ve Asya milletlerini daha aktif bir şekilde desteklemesi beklenmelidir. Fakat her ne kadar Kemalist söylemde "mazlum milletlere örnek olmak" sıklıkla dile getirilen bir ifade olmuşsa da, pratikte Türkiye bu konuda aktif bir dış politika takip etmemiş, aksine ilerleyen yıllarda Batılı ülkelerle ilişkilerini geliştirme yoluna gitmiştir. Batılı ülkelerle ilişkilerinin bozulduğu zamanlarda bile bunun nedeni anti-emperyalist ya da Batı karşıtı bir ideolojiden ziyade, realist ve pragmatik bir dış politika izlenmesi olmuştur. Kemalist elit Batılı devletlerin kendi aralarındaki farklılıkları kullanmış, diplomatik alanda yeni kurulan cumhuriyetin güvenlik ve bütünlüğünü merkeze alan bir politika takip etmiştir.

Kemalist elitin Batılı ülkelerle kurulan pragmatizme dayalı bu ilişkisinin temel nedeni, iç siyasetteki Kemalist ideolojinin etkisinden ziyade uluslararası ortamın belirlediği jeostratejik gerekliliklerdir. 1930’lu yıllarda artmakta olan İtalyan ve Alman tehdidi Kemalist eliti güvenlik merkezli pragmatik politikalar izlemeye itmiştir. Güvenliğini Balkanlar ve Akdeniz'den kaynaklanan tehditlerin altında gören karar alıcılar, Batılı devletlerin aralarındaki politika farklılıklarını iyi kullanmış, Türkiye'yi Avrupa'da yayılmakta olan uluslararası felaketten kurtarmaya odaklanmış, gerçekçi ve itidalli bir politika takip etmişlerdir. ${ }^{36}$

Bu çerçevede 1930'lu yıllar Türk dış politikası, uluslararası statükonun korunmasını hedef almış, bölgesel istikrarın sağlanmasını ise en önemli öncelik olarak kabul etmiştir. Türkiye bu hedef doğrultusunda bu yıllarda özellikle Balkanlar ve Akdeniz'de bağımsız ve aktif bir diplomasi izlemiştir. ${ }^{37}$ Bu dönemde Türkiye'nin girişimleri ile başlatılan Balkan Paktı ve Sadabat Paktı gibi ittifaklar ile uluslararası ve bölgesel istikrara aktif katkı sağlanmaya çalışılmıştır. Türkiye, 1937’ye kadar yükselen İtalyan faşizminin muhtemel zararlarını bertaraf etmeye yoğunlaşırken, 1938 ve sonrasında güvenlik diplomasisinde Alman tehdidine de önemli bir yer ayırmıştır. ${ }^{38}$ Bu kapsamda İkinci Dünya Savaşı́nın hemen öncesinde güvenlik endişelerine uygun politikalar üreten Türkiye, Boğazları silahlandırma hakkını elde etmeye, İtalyan ve Alman tehditlerine karşı Fransa ve İngiltere ile ittifaklar kurmaya ve Sovyet Rusya ile mevcut barış antlaşmasının uzatılmasını sağlamaya çalışmış ve bu hedeflerinde de büyük oranda başarılı olmuştur.

\footnotetext{
34 Aydın, "Determinants of Turkish Foreign Policy", s.171.

35 Ibid.

36 Barlas, "Turkish Diplomacy in the Balkans and the Mediterranean".

37 Ibid.

38 William Hale, Turkish Foreign Policy since 1774, (3. Baskı), Routledge, Abingdon, 2013, s.48.
} 
Türkiye, 1930’ların başlarında, özellikle Avrupa'da yükselen faşist tehlikeye karşı Balkanlar’ın istikrarına yoğunlaşmıştır. Bu bağlamda ilk olarak Yunanistan ile münasebete geçilmiş, uluslararası uzlaşmazlıkların giderilmesine çalışılmıştır. Ekim 1930'da Yunanistan Başbakanı Eleftherios Venizelos Türkiye'de ağırlanmış, takip eden yılda da Başbakan İsmet İnönü Yunanistan'ı ziyaret etmiştir. 1930 yılında bir barış, dostluk ve karşılıklı iyi niyet antlaşması imzalanan Yunanistan'la ilişkilerin düzeltilmesi uluslararası topluma verilen mesaj açısından önemlidir. 1933'de Yunanistan'la imzalanan ikinci bir antlaşma ile de karşılıklı saldırmazlık ve özellikle İtalyan tehdidine karşı güvenlik işbirliğinin yolu açılmıştır. Bu anlaşma ile Türkiye, Batılı ülkeler ile egemenlik ve bağımsızlık ilkeleri ekseninde eşit ve uzlaşmacı bir politika izlemek istediği, dahası Batılı ülkelere potansiyel ortak olabileceği yönündeki sinyalleri açık şekilde vermiştir. ${ }^{39}$

Türkiye'nin Balkanlardaki diplomatik faaliyetleri Yunanistan ile sınırlı kalmamıştır. İtalya’nın 1930’ların başında Onikiadaları silahlandırmaya başlaması ve Güneybatı Anadolu’da toprak iddia etmesiyle birlikte alarma geçen Ankara, bölgesel kolektif güvenlik düzenlemeleri oluşturmaya çalışmıştır. 1934'de Türkiye, Yunanistan, Yugoslavya ve Romanya arasında imzalanan Balkan Paktı ile bölgesel güvenlik planları somut netice vermiştir. Bunun yanı sıra Türkiye, Balkanlardaki ülkelerle ikili ilişkilere ayrı bir önem atfetmiş, 1935'de İtalya'nın Habeşistan'ı işgali ile birlikte uluslararası toplumda olduğu gibi Türkiye'de de İtalya tehdidi en önemli güvenlik meselesi olarak ele alınmaya başlanmıştır. Uluslararası platformlarda İtalya'ya yeni müeyyideler uygulanmasını açıktan desteklemeye başlayan Türkiye, ${ }^{40}$ Akdeniz'de İtalyanları durduracak Balkan Paktı benzeri bir antlaşma imzalanması için çalışmış fakat başarılı olamamıştır. Yine de Türkiye’nin bu başarısızlığa rağmen Akdeniz'de uluslararası toplumun İtalyan tehdidine karşı uyarılmasını öncelikleri arasına koyan aktif bir diplomasi takip etmeyi sürdürdüğ̈ görülmektedir. ${ }^{41}$

Balkanlar, 1930’lu yıllarda Türkiye'nin diplomatik çabalarının en fazla yoğunlaştığı bölge olmasına rağmen, hükümet Ortadoğu'daki ilişkilere de önem vermiş, bölgesel istikrarı burada da dış politika önceliği olarak savunmuştur. 1932'de sınırdaki hareketlenmelere ve uyuşmazlıklara son vermek amacıyla İran ile bir anlaşma imzalanmış, yüzyıllardır değişmeyen Türkiye-İran sınırı garanti altına alınmıştır. 1937'de ise Irak, İran ve Afganistan'ın katılımları ile Sadabat Paktı imzalanmış ve bu antlaşma ile imzacı ülkeler birbirlerinin toprak bütünlüğünü garanti altına alarak, sınır bölgelerindeki Kürt isyanlarına karşı birlikte hareket etmeyi taahhüt etmişlerdir. ${ }^{42}$ Türkiye bu antlaşma ile özellikle İtalya’nın Habeşistan’ı işgali sonrasında Avrupa'daki muhtemel bir çatışmada doğu sınırlarını garanti altına almak istemiştir. ${ }^{43}$

1930’lu yılların sonu, İkinci Dünya Savaşının arifesinde, Türkiye bütün diplomatik enerjisini muhtemel bir İtalyan ve Alman saldırısına karşı̇ İngiltere ve Fransa’nın ittifakını kazanmaya harcamıştır. Yoğun bir diplomasi trafiğinin sonunda Türkiye Mayıs 1939'da İngiltere, Haziran 1939'da da Fransa ile karşılıklı güvenlik antlaşmaları imzalamayı başarmıştır. Ekim 1939'da ise Türkiye, İngiltere ve Fransa arasında üçlü karşılıklı saldırmazlık ve savunma antlaşması imzalanmıştır. Bu çerçevede Türkiye'nin Akdeniz'de her hangi bir saldırıya uğraması durumunda İngiltere ve Fransa, Türkiye'ye yardım etmeyi kabul etmişler, İngiltere ve Fransa'nın Akdeniz'de saldırıya uğraması durumunda da Türkiye bu ülkelere destek vermeyi taahhüt etmiştir. Bu yıllar boyunca Almanya, Türkiye'yi siyasi

39 Barlas, "Turkish Diplomacy in the Balkans and the Mediterranean", s.443-4.

40 Hale, Turkish Foreign Policy since 1774, s.45.

41 Barlas, “Turkish Diplomacy in the Balkans and the Mediterranean”, s.464.

42 Kösebalaban, Turkish Foreign Policy, s.57.

43 Mufti, Daring and Caution in Turkish Strategic Culture, s.25. 
baskı altına alıp İngiltere ve Fransa ile imzaladığı antlaşmaları engellemeye çalışmıştır. Bu dönemde Türk diplomasisinin zorluklarından birisi de İngiltere ve Fransa ile antlaşmalar imzalanırken, Almanya ve Sovyet Rusya ile de dostluğun devamını sağlamak olmuştur. ${ }^{44}$

1936'da İstanbul ve Çanakkale boğazlarının Türkiye tarafından silahlandırılmasını sağlayan Montrö Antlaşması ve 1939 'da Hatay'ın Türkiye topraklarına dahil edilmesi statüko merkezli politikaların 1930'lu yıllardaki iki istisnasıdır. Fakat bu iki olayda da Kemalist elit büyük devletler arasındaki anlaşmazlıkları ve rekabeti ustaca kullanmış, diplomatik çabaların sonucunda neticeye ulaşmıştır. Lozan Antlaşması Türkiye’nin Boğazlar üzerindeki egemenliğini sınırlandırmaktaydı. Fakat İngiltere ve Balkan Paktı üyelerinin desteği ile Türkiye 1936'da yeni bir konferansın toplanmasını sağlayarak, Boğazlar üzerindeki hâkimiyetini tescil ettirmiştir. Avrupa'da faşist ve liberal hükümetler arasındaki rekabet bu konferans için başarı ile kullanılmıştır. ${ }^{45}$ Hatay meselesinde de Türkiye uluslararası ortamı diplomatik bir başarı için kullanmasını bilmiştir. Hatay üzerinde Suriye'deki manda rejimi sonrasında da etkisini sürdüren Fransa, artan Alman ve İtalyan tehdidine karşı Türkiye'nin desteğini kaybetmek istememiş, sorunun çözümü konusunda Türkiye'nin tezlerine yakın bir pozisyon almıştır. Bu çerçevede Hatay 1938'de bağımsız bir devlet olarak tanınmış, bir sonraki yıl yapılan referandum ile de Türkiye'ye bağlanmıştır. ${ }^{46}$

1930’lu yıllar Türk dış politikasını “itidal” kelimesi ile karakterize etmek her halde yanlış olmaz. 1920’li yılların sonu itibari ile iç siyasette denetimini sağlama alan Kemalist elit, takip eden on yılda aktif bir dış politika izlemiş, ancak uluslararası statükoyu tehdit edecek adımlardan olabildiğince kaçınmıştır. 1930’lu yıllar Avrupa'da faşizmin yükselişe geçtiği ve uluslararası sistemi tehdit ettiği yıllardır. Uluslararası ortamın bu denli tehditkâr oluşu Türkiye'yi itidal ve statükodan ayrılmamaya itmiştir. Fakat Türkiye bu dönemde bağımsız ve aktif bir diplomasi izlemekten de geri durmamıştır. Bölgesinde çeşitli ittifakların önünü açmış, büyük güçlerle işbirliğinde önemli diplomatik başarılara imza atmıştır. Çalışmanın başında ifade edilen soruya dönecek olursak Türkiye iç siyasette ikame ettiği Kemalizm'in gereği olan anti-emperyalist bir dış politikayı uluslararası ortamın bıraktığı manevra alanının dar oluşu nedeniyle harekete geçirememiş, sömürge olarak yaşayan milletlere destek vermemiş, pragmatik ama aktif bir politika ile olabildiğince dost kazanmaya ve uluslararası toplum tarafından kabul edilmeye yoğunlaşmıştır. Aşağıda ele alınacağı üzere, 2011-2015 arası dış politikasının belirlenmesinde ise tamamen farklı bir uluslararası ortamla karşı karşıya kalınmıştır.

\section{1-2015 Arası Türk Dış Politikası}

1930’lu yıllardaki Kemalist elite benzer biçimde Adalet ve Kalkınma Partisi (AKP) yöneticileri 2010’lu yıllara gelindiğinde Türkiye'de siyasal kontrolü ele geçirmişlerdir. 2007-2011 arasında AKP yöneticileri kendilerini Kemalist elite benzer şartlar altında bulmuşlar, uluslararası ortam her iki durumda da aktörlerin dış politika seçeneklerini sınırlandırmıştır. Ne var ki AKP, 2011'de başlayan Arap Baharının ardından oluşan bölgesel gelişmeler sayesinde daha az sınırlayıcı bir uluslararası ortamla muhatap olmuştur. Bu ortamda, 2011-2015 döneminde Türkiye, iç siyasette hegemonyasını kuran bir aktörün uluslararası şartların da sınırlandırmadığı durumlarda nasıl ideolojik bir dış politikaya kayabileceğini gösteren örnek olmuştur.

44 Selim Deringil, Turkish Foreign Policy During the Second World War: Active Neutrality, Cambridge University Press, New York, 2004.

45 A. L. Macfie, “The Straits Question: The Conference of Montreux”, Balkan Studies, Cilt 13 No.2, 1972, s.203-219.

46 Avedis K. Sanjian, “The Sanjak of Alexandretta (Hatay): Its Impact on Turkish-Syrian Relations, 1939-1956”, Middle East Journal, Cilt 10 No.4, 1956, s.379-94. 
2002'de iktidara gelen AKP döneminde Türkiye köklü değişimler yaşamıştır. 2002-2011 arasına tekabül eden iktidarının ilk iki döneminde AKP, çeşitli reformları hayata geçirmiş, ülkeyi özellikle 1990’ların ortasında ordunun siyasete müdahalesi ile özgürlüklerin sınırlandığı bir yapıdan görece reformist bir sürece geçirebilmiştir. Hatırlanacak olursa, 1997'de ordunun siyaseti düzenleme çabaları sonucunda sivil hükümet istifaya zorlanmış, Anayasa Mahkemesi koalisyonun büyük ortağı Refah Partisi'ni laikliği tehdit ettiği gerekçesi ile kapatmış, dini gruplara yakın dernek ve vakıflar üzerinde baskı oluşturulmuş ve Yüksek Öğretim Kurumu üniversitelerde başörtüsünü yasaklamıştır. ${ }^{47}$

2001'de Refah Partisi'nin yerine kurulan Fazilet Partisi'nin de Anayasa Mahkemesi tarafından kapatılmasından sonra kurulan AKP, kendisine İslamcı ideoloji yerine, "muhafazakâr demokrasi" olarak adlandırdığı reformist bir söylem geliştirmiştir. ${ }^{48} \mathrm{Bu}$ çerçevede 2002-2011 arasında AKP sadece İslamcı tabanın değil, liberaller ile gayrimüslim azınlıkları da içeren farklı kesimlerin desteğini alarak sivil ve siyasi özgürlüklerin önünü açmış, gerçekleştirdiği reformlarla 2005'de Türkiye’nin AB ile üyelik müzakerelerine başlamasını sağlamıştır. ${ }^{49}$ Oluşan bu geniş halkalı demokratik koalisyon, ordunun siyaset üzerindeki vesayetini zayıflatarak sivil siyasetin önünü açmıştır. ${ }^{50}$ İç siyasette azınlıkların statüsünün düzeltilmesinden sivil özgürlükler alanına kadar bir dizi reform gerçekleştirilirken, ekonomide kalkınma eksenli bir politika takip edilmiş, ihracat ve büyümeye öncelik verilmiştir. Dış politikada ise $A B$ üyeliği güçlü şekilde desteklenmiş, özellikle 2007 sonrası Ortadoğu, Rusya ve Balkanlarla ilişkiler geliştirilmiş olsa bile, bu açılımlar Batı ile ilişkileri tamamlayacak bir düzlemde ilerlemiştir. Bu dönemle ilgili olarak yapılan değerlendirmelerin büyük kısmı AKP iktidarının ilk iki döneminde İslam, laiklik ve demokrasinin nasıl bir arada olabileceğinin güzel bir örneğinin ortaya koyulduğunu ileri sürmektedirler. ${ }^{51}$

Öte yandan, 2011 seçimleri ardından reformların hızlanarak sürmesi beklenirken, iç ve dış çeşitli gelişmeler, Arap Baharını takiben demokratik yönetimde zayıllamaya neden olmuş, özellikle Mayıs-Haziran 2013'de gelişen “Gezi Parkı Protestoları” sonrasında muhalefet etmede sıkıntılar ortaya çıkmaya başlamıştır. ${ }^{52} \mathrm{Bu}$ durum, dört bakan hakkında yolsuzluk iddialarının da gündeme geldiği “17-25 Aralık Süreci” ile artarak devam etmiştir. Takip eden dönemde yapılan çeşitli kanuni düzenlemeler ile yürütmenin yargı üzerindeki gücünün artırıldığı ve hükümetin kendisine yönelen eleştirileri sınırlandırma ve cezalandırma yoluna girdiği iddia edilmiştir. ${ }^{53}$

47 Ali Bayramoğlu, 28 Şubat: Bir Müdahalenin Güncesi, Birey Yayınları, İstanbul, 2001.

48 Ziya Öniş, "Political Islam at the Crossroads: From Hegemony to Co-Existence”, Contemporary Politics, Cilt 7 No.3, 2001, s.281-298.

49 “EU Opens Turkey Membership Talks”, BBC News, 4 Ekim 2005, http://news.bbc.co.uk/2/hi/europe/4305500.stm.

50 Ramazan Kılınç, “Critical Junctures, Catalysts, and Democratic Consolidation in Turkey”, Political Science Quarterly, Cilt 129 No.2, 2014, s.293-318; Ramazan Kılınç, "International Pressure, Domestic Politics, and the Dynamics of Religious Freedom: Evidence from Turkey”, Comparative Politics, Cilt 46 No.2, 2014, s.127-145.

51 Jean-Loup Samaan, “The Rise and Fall of the 'Turkish Model' in the Arab World”, Turkish Policy Quarterly, Cilt 12 No.3, 2013, s.61-69; Gamze Çavdar, "Islamist New Thinking in Turkey: A Model for Political Learning?”, Political Science Quarterly, Cilt 121 No.4, 2006, s.477-497; İhsan D. Dagi, “Transformation of Islamic Political Identity in Turkey: Rethinking West and Westernization”, Turkish Studies, Cilt 6 No.2, 2005, s.21-37; Malik Mufti, “The Many-Colored Cloak: Evolving Conceptions of Democracy in Islamic Political Thought”, American Journal of Islamic Social Sciences, Cilt 27 No.1, 2010, s.1-27.

52 Gezi protestoları ve sonuçları ile ilgili bir çalışma için bkz. Umut Özkırımlı (der), The Making of a Protest Movement in Turkey: \#OccupyGezi, Palgrave MacMillan, London, 2014.

53 Bkz. Susan Corke, et al., Democracy in Crisis: Corruption, Media and Power in Turkey, New York, Freedom House, 2014; Fait Muadini, "The Politics between the Justice and Development Party and the Gülen Movement in Turkey: Issues of Human Rights and Rising Authoritarianism”, Muslim World Journal of Human Rights, Cilt 12 No.1, 2015, s.99-122. 
Liberal demokratik politikaları doğurması beklenen açılım süreci ise Haziran 2015 genel seçimlerinin ardından sona ermiştir. Haziran seçimlerinde daha önce bir Kürt siyasi hareketi olarak gelişen Halkların Demokrasi Partisi'nin (HDP) sol-liberal bir söylemle barajı geçmesi sonucu AKP'nin tek parti iktidarını kaybetmesi ihtimalinin belirmesi, fakat herhangi bir koalisyon hükümetinin kurulamaması nedeniyle 1 Kasım'da yenilenen seçimlerde milliyetçi oyları hedeflemesiyle birlikte, 2012'den itibaren PKK ile sürdürülen müzakereler, yeniden başlayan PKK saldırıları ve güvenlik güçlerinin sert cevabı ile sona ermiştir. ${ }^{54}$

Bu dönemde hükümet 2000’li yılların aksine, Türkiye’nin İslami kimliğini daha sık vurgulamaya başlamıştır. Bir taraftan, 2000'li yıllar boyunca ordunun siyaset üzerindeki vesayetinin bitmesi takip eden dönemde AKP'ye daha geniş bir manevra alanı sağlarken, Arap Baharı ile Batı́nın Türkiye'ye ihtiyacının artması ve Arap ülkelerinde İslamcı partilerin iktidara gelme ihtimali de AKP'yi zamanla daha İslamcı bir söyleme çekmiştir. ${ }^{55}$ Popülist İslamcılık, muhafazakâr demokrasi fikrinin yerini almış, kamusal tartışma, toplantı, konuşma ve siyasi reklamlarda parti ve liderinin İslam dünyası için önemi vurgulanmış, bütün İslam dünyasını kapsayan bir söylem oluşturulmaya çalışılmıştır. ${ }^{56}$ Türkiye'nin bu dönemde ara sıra mezhepçilik sınırlarına yaklaşan Mısır, Suriye ve Irak’a yönelik dış politikası hükümet temsilcileri ya da hükümete yakın aydınlar tarafından ümmetçi bir söylemle meşrulaştııılmış, ${ }^{57}$ iç politikada da benzer bir popülist söylemle iktidar tekeli sağlamlaştırılmıştır.

AKP’nin iktidarda kaldığı dönem boyunca değişen dış politikası yukarıda ortaya konulan teorik çerçeve ile uyum halindedir. AKP iktidarının ilk döneminde (2002-2007), yani hem iç siyasetin hem de uluslararası ortamın sınırlayıcı olduğu atmosferde, statüko bazlı bir dış politika yürütülmüştür. $\mathrm{Bu}$ dönem politikaları ne içeride devlet geleneğini, ne de dışarıda uluslararası güçleri rahatsız edecek politikalardır. Hükümet $A B D$ ve $A B$ ile ilişkilerine dikkat etmiş, $A B$ üyeliğini en önemli dış politika gündemi yapmıştır. Ortadoğu'da İsrail ile ilişkilere önem vermiş, İsrail'in Filistin’i işgaline karşı sert eleştirel bir tavır yerine iki taraf arasında arabulucu rolünü oynamaya çalışmıştır. Yine aynı şekilde, ABD’nin Ortadoğu'daki müttefikleri ile ilişkilerini üst seviyede tutmuştur. Bu dönemde iç siyaset açısından geleneksel yörüngenin dışında sayılabilecek tek açılım hükümetin Kıbrıs konusunda BM’nin hazırladığı çözüm planına verdiği destektir. Fakat burada da geleneksel Türk dış politikası önceliklerinden olan $\mathrm{AB}$ üyeliğine yönelik bir yatırım söz konusudur.

2007-2011 arasında AKP iç siyasetteki kontrolünü konsolide etmiş, ordunun siyaseti şekillendirme kabiliyeti büyük ölçüde yok edilmiş, fakat uluslararası ortamda önceki dönemdeki statüko yaklaşımı devam etmiştir. Yine de iç siyasette eli güçlenen AKP bu dönemde 2002-2007 dönemine nazaran daha müdahil bir dış politika izlemiştir. Bu dönemde Türkiye’nin komşuları ile ilişkileri geliştirilmiş, özellikle Ortadoğu'da birçok ülke ile esnek vize rejimine geçilmiş, uluslararası ticarette yeni açılımlar sağlanmış, Batı́nın çıkarlarına aykııı olmayan konularda Ortadoğu, Orta Asya ve Balkanlar'da ikili sorunların çözümünde arabuluculuklar gerçekleştirilmiştir. Bu dönemde Başbakanlık Dış Politika Baş Danışmanı olan Ahmet Davutoğlu tarafından geliştirilen "komşularla sıfır sorun” yaklaşımı devlet politikası haline gelmiş, diplomatik kanallar açık tutularak Türkiye

54 Henri Barkey, “Turkey's Turmoil: Why Erdogan and the Kurds are Both to Blame”, The National Interest, 25 Eylül 2015.

55 Turan Kayaoglu, "Getting Turkey Back on Track to Democracy, Human Rights and Religious Freedom”, The Review of Faith and International Affairs, Cilt 14 No.2, 2016, s.14-22.

56 “Erdoğan: Derdimiz Mezhepçilik Değil, İslam”, Yeni Akit, 1 Ağustos 2015.

57 Özkan, “Turkey, Davutoğlu and the Idea of Pan-Islamism”. 
bölgesinin aktif yumuşak gücü haline getirilmiştir. ${ }^{58}$ Yine de, bu dönemde dış politikada yeni açılımlar yapılsa da, uluslararası statükoyu tehdit edecek ciddi politika kaymaları yaşanmamıştır. Dönemin en önemli statüko karşıtı dış politikası Türkiye'nin İsrail ile ilişkilerinde özellikle 2010'dan sonra yaşanan kötüleşme ve ortaya çıkan kapsamlı sorunlardır. ${ }^{59} \mathrm{Bu}$ durumun normalde ABD’yi rahatsız etmesi ve Türk-Amerikan ilişkilerini zedelemesi beklenirken, Türkiye'nin diğer Ortadoğu ülkeleri ile geliştirdiği yeni açılımların doğal bir sonucu olan bu gelişme Türkiye’nin geleneksel Batı-merkezli dış ilişkilerini çok fazla sarsmamıştır. İsrail'de bu dönemde radikal sağ hükümetlerin iktidarda oluşu ile Batı'da da İsrail ile ilgili eleştirel seslerin yükselmeye başlamış olması Türkiye’nin bu değişimin tek sorumlusu olarak suçlanmasını engellemiştir. Bu nedenle, özünde bölgedeki uluslararası statükoya ters olan bu değişim, Türkiye'yi uluslararası sistemde çok da zora sokmamıştır. ${ }^{60}$

2011'den sonra ise AKP iç siyasette hâkimiyetini tam olarak sağlarken, uluslararası ortamda da Arap Baharı sonrası yeni manevra alanları açılmıştır. Bu dönem, iç politikada bürokratik vesayetin zayıflatıldığı fakat 1982 anayasası ile kurulan vesayetçi kurumların yerini demokratik kurumlara henüz devretmediği bir dönem olmuştur. 2011 sonrası dönemde AKP bu kurumları ve Meclis'teki çoğunluğunu kullanarak ülkedeki siyasal kontrolünü güçlendirmiştir.

Bu dönemde uluslararası ortamda da önemli değişiklikler meydana gelmiştir. ABD’nin Irak'tan çekilmesi ve Arap Baharı ile birlikte Ortadoğu siyasi istikrar açısından görecekırılgan bir döneme girmiş, Arap Baharının ilk aylarında Tunus ve Mısır’daki yönetim değişiklikleri birçok gözlemcide olduğu gibi, AKP lider kadrosunda da Ortadoğu'da İslamcıların iktidara taşınacağı kanaatini oluşturmuştur. ${ }^{61}$ AKP'nin bu dönemde İslamcı bir söylem geliştirmesinde bu kanaatin payı büyüktür. İslamcıların daha etkili olacağını var saydığı Ortadoğu'da bölgesel liderlik hesaplarıyla hareket eden AKP elitleri, hem söylemlerine hem de dış politikalarına bunu yansıtmıştır. ${ }^{62}$ Ortadoğu'daki bu değişim ümidinin yerini keşmekeş ve şiddete bıraktığı 2013 sonrası dönemde ise, AKP yeni jeostratejik ortamın ABD ve $A B$ ülkelerini Türkiye ile birlikte hareket etmeye zorlamasının avantajlarını kullanmıştır. Gerek Suriye'deki iç savaş ve Irak'taki istikrarsızlı̆̆ı kullanarak yükselen Irak ve Şam İslam Devleti (IŞID) gibi radikal gruplarla mücadele, gerekse hızla büyüyen Suriyeli mülteciler krizi ABD ve AB'yi Türkiye ile koordineli hareket etmeye zorlamıştır. Bu nedenle Batı ülkeleri Türkiye’nin içeride otoriterleşmesine, dışarda ise müdahaleci dış politikasına göz yummuşlardır. Bu iç ve dış şartlar altında AKP, zamanla pragmatizmden ideoloji eksenli dış politikaya kaymıştır.

Türkiye'nin Suriye politikası ideolojik dış politika yapımının etkisini en açık gösterdiği alanlardan biridir. Suriye'de Mart 2011'de Esad rejimine karşı sokak gösterilerinin başlamasını takiben Türkiye, Suriye ile son on yılda geliştirdiği ilişkilerin kredisini kullanarak siyasi bir çözüm için çaba göstermiştir. Fakat Esad rejiminin muhaliflere karşı silahla cevap vermesinin ardından kısa süre içinde Suriye'de iç savaş başlamış, Türkiye 2011'in sonundan itibaren muhaliflerin güçlü destekçisi olmuştur. 2014 yazında IŞİD’in Musul'u işgal edip kendi devletini ilan etmesine kadar geçen sürede Türkiye'nin Suriye konusunda uluslararası sistemle, özellikle de Batı ile bazı ayrılıkları olsa da farklı çizgide bir siyaset izlediğini söylemek zordur. O dönemde Batı ülkelerinin birçoğu da Esad rejimine

58 Ahmet Sözen, “A Paradigm Shift in Turkish Foreign Policy: Transition and Challenges”, Turkish Studies, Cilt 11 No.1, 2010, s.103-123.

59 Erkan Ertosun, Filistin Politikamı: Camp David'den Mavi Marmara'ya, İstanbul, Kaknüs Yayınları, 2014.

60 Hasan Kösebalaban, “The Crisis in Turkish-Israeli Relations: What is Its Strategic Significance?”, Middle East Policy, Cilt 27 No.3, 2010, s.36-50.

61 Jonathan Shanzar ve Merve Tahiroğlu, “Ankara’s Failure: How Turkey Lost the Arab Spring”, Foreign Affairs, 25 Ocak 2016.

62 Özkan, “Turkey, Davutoğlu and the Idea of Pan-Islamism”. 
karşı muhalifleri desteklemiştir. Fakat Batı ülkeleri muhalifler içerisinde radikal unsurların güçlenip Suriye'nin kontrolünü ele geçirmesi endişesi ile silahlı destek vermekten kaçınırken, Türkiye, Suudi Arabistan ve Katar'la birlikte Batı'ya göre daha az seçici olmuştur. ${ }^{63} 2014$ sonrasında ise Türkiye tıpkı Batı ülkeleri gibi hem IŞİD hem de Esad rejimine karşı konumlanmıştır. Ne var ki bu dönemde de Türkiye tedrici olarak, Esad ve IŞİD karşısındaki vurgusu ve öncelikleri bakımından Batı'dan uzaklaşmıştır. Türkiye Esad rejimini Suriye'deki sorunların temel nedeni olarak görürken, Batı IŞİD ve radikalizmi daha önemli bir problem olarak algılamıştır. ${ }^{64}$ Türkiye'nin içeride Kürt sorunu ile ilgili başlatmış olduğu çözüm sürecini 2015 ortalarında sonlandırmasının ardından Batı ile farklılıklar artmış, IŞİD’e karşı Suriye'de savaşan Kürt grupların Türkiye'deki terör olayları ile ilişkili görülmesi ve Türkiye'nin bu gruplara karşı gerçekleştirdiği askeri operasyonlar Batı ile Suriye konusundaki farklılıkları daha belirgin hale getirmiştir. Bu çerçevede uluslararası toplumda da Türkiye'nin IŞı̇D’e karşı yeterince tavır almadığı konusunda bir kanaat oluşmuştur. ${ }^{65}$

Türkiye’nin Mısır konusundaki dış politikası popülist İslamcılık ideolojisinin etkisini belki de en fazla gösterdiği alandır. Mısır'da Hüsnü Mübarek rejimine karşı gösterilerin başladığı Ocak 2011'de Türkiye protestocuları destekleme konusunda bir süre kararsız kalmış, fakat kısa sürede Mübarek istifaya davet edilerek göstericilerin demokratik taleplerinin desteklenmesi noktasına gelinmiştir. Mübarek rejiminin düşmesi ve ilk rekabetçi seçimlerde Müslüman Kardeşler’in adayı olan Muhammed Mursi’nin başkan seçilmesinin ardından Türkiye, Mısır ile ilişkilerini hızlı şekilde ilerletmiştir. Mursi AKP parti kongresine davet edilmiş ve Mısır'da istikrarın sağlanması için maddi yardım teklif edilmiştir. 2013 yazında Mısır'da gelişen iktidar karşıtı gösterilerin bir askeri darbe ile neticelenmesi ve Başkan Mursi'nin hapse atılması Türkiye'de en üst düzeyde eleştirilmiş ve Türkiye askeri yönetimin başkanlığa atadığı Abdülfettah Sisi’yi tanımadığını ilan etmiştir. ${ }^{66}$ Türkiye bu dönemde darbeyi takiben gelişen protestoların devamını teşvik etmiş, hükümet yaptığı açıklamalar ile Mısır ile gerilimi üst seviyeye çıkarmıştır. Müslüman Kardeşler'den tutuklananlar ile ilgili tepki gösterilmiş, AKP mitinglerinde Mısır'daki protestocuların "Rabia” sembolü kullanılmaya başlanmıştır. Türkiye bu dönemde Batı'yı da Mısır'daki darbeden sorumlu tutarak, eleştirilerini yoğunlaştırmıştır. ${ }^{67}$ 2015 sonu itibariyle Türkiye’nin Ortadoğu'nun önemli ülkelerinden biri olan Mısır'la ilişkileri henüz normalleştirilememiştir.

2011 sonrası Türkiye’nin Irak politikasında da ideolojik yaklaşımların etkisini görmek mümkündür. ABD askerlerinin Aralık 2011'de Irak'tan çekilmesinden sonra Irak merkezi hükümeti mezhepçi tutumunu sertleştirmiş, Sünni siyasetçiler ve bürokratlar üzerinde yoğun baskı kurmuştur. Amerikan askerlerinin ayrılışını takiben Cumhurbaşkanı Yardımcısı Sünni lider Tarık Haşimi hakkında tutuklama kararıçıkarılmış ve çok sayıda Sünni idareci hakkında yargısal süreçler başlatılarak Sünnilerin etkileri kırılmak istenmiştir. ${ }^{68} \mathrm{Bu}$ süreçte Türkiye Sünni grupların hamisi rolüne soyunmuş ve Irak merkezi yönetimi ile ilişkilerinin seviyesini fark edilebilir şekilde düşürmüştür. Haşimi’ye sığınma sağlayan Türkiye, merkezi yönetimle aralarında petrol paylaşımı konusunda uyuşmazlıklar bulunan

63 David E. Sanger, "Rebel Arms Flow is Said to Benefit Jihadists in Syria”, New York Times, 15 Ekim 2012.

64 Michael M. Gunter, "Iraq, Syria, Isis, and the Kurds: Geostrategic Concerns for the U.S. and Turkey”, Middle East Policy, Cilt 22 No.1, 2015, s.102-111.

65 David Graeber, “Turkey Could Cut Off Islamic State’s Supply Lines. So Why Does not It”, Guardian, 18 Kasım 2015.

66 Mehmet Yegin, "Turkey's Reaction to the Coup in Egypt in Comparison with the US and Israel”, Journal of Balkan and Near Eastern Studies, Cilt 18 No.4, 2016, s.407-421.

67 Ahmet T. Kuru, "Turkey's Failed Policy toward the Arab Spring: Three Levels of Analysis”, Mediterranean Quarterly, Cilt 26 No.3, 2015, s.94-116.

68 Dexter Filkins, "What We Left Behind”, The New Yorker, 28 Nisan 2014. 
Kuzey Irak Bölgesel Yönetimi ile de doğrudan temasa geçerek, Kerkük petrollerinin satışı konusunda ABD’nin de karşı olduğu anlaşmalar imzalamıştır. ${ }^{69}$ Ardından Kuzey Irak Bölgesel Yönetimi lideri Mesut Barzani Türkiye'de ağırlanarak, Başbakan Erdoğan ile birlikte Diyarbakır'da geniş katılımlı bir miting yapmıştır. ${ }^{70}$ Türkiye'nin Irak Kürtlerine yönelik geleneksel politikası dikkate alındığında bunun çok önemli bir hamle olduğu görülür. Devlet politikası olarak bağımsız Kürt devletine sıcak bakmayan Türkiye'nin bu dönemdeki hamleleri bağımsız bir devlet olma yolunda Kuzey Irak Kürtlerinin elini güçlendirme potansiyeline sahiptir. Dahası, merkezi Irak yönetimi ile ilişkilerin bozulup bölgesel Kürt yönetimi ile temasların artırılması statüko ile çelişmektedir. Irak'ta Kürtlerin merkezi hükümet aleyhine desteklenmesi ve Sünni muhalif gruplarla sıkı ilişkiler Türkiye’nin komşularının toprak bütünlügüne saygıyı öncelleyen geleneksel dış politikasından ayrıldığına işaret etmektedir. O kadar ki, 2015'de Kürt sorunu şiddeti içeren bir ivme kazandığında bile Türkiye’nin Kuzey Irak Kürt Yönetimi ile ilişkileri bu süreçten pek etkilenmeden devam etmiştir. ${ }^{71}$

Türkiye'nin İran'la ilişkileri inişli çıkışlı olsa da, 2011-2015 arası dönemde AKP’nin siyasi tercihlerinin etkisini bu ilişkilerde de görmek mümkündür. Türkiye’de İslamcılık akımı geleneksel olarak Ali Şeriati gibi İranlı düşünürlerin fikirlerinden etkilenmiş, İran devrimi sonrasında da ivme kazanmıştır. $^{72}$ Türk İslamcılarının İran sempatisi kendini 2011 sonrası Türk dış politikasında göstermiş, İran'ın Suriye iç savaşında Esad rejimini desteklemesine ve Türkiye karşıtı bir tavır almasına rağmen Türkiye-İ́ran ile ilişkilerinde seviye düşüklüğüne gidilmemiştir. ${ }^{73}$ Benzer şekilde Türkiye bir yandan Suriye ve Yemen sorunlarında Suudi Arabistan ile ittifak kurarken, diğer yandan İran ile ikili ilişkilerini de devam ettirmeyi önemli görmüştür. Şunu da belirtmek gerekir ki, Türkiye'nin İran'dan büyük oranda doğal gaz ithal etmekte oluşu da bu ilişkileri etkilemiştir. Yine de Türkiye'nin 2015 güzünde yine enerji ve ticaret bakımından bağımlı olduğu Rusya'yla arasında çıan kriz sonrası aynı pragmatik tavrı göstermemiş olması, İran ile ilişkilerde kimlik ve ideolojinin etkisine işaret etmektedir.

AKP'nin 2011-2015 arasında ideoloji eksenli dış politikaya kayışının en belirgin olduğu alanlardan biri Türkiye'nin Batı ve özellikle de ABD ile ilişkileridir. Türkiye, 2007-2011 arasında aktif bir dış politika ile ilişkilerini çeşitlendirirken, dış politika söylem ve eylemlerinde Batı karşıtlığına girmemiş, yeni dış politika inisiyatiflerini mevcut ilişkilerini tamamlayan ve çeşitlendiren girişimler olarak sunmuştur. ${ }^{74} \mathrm{Ne}$ var ki 2011 sonrasında Batı ve ABD karşıtlığı hem iç politika malzemesi olarak kullanılmış, hem de zaman zaman dış politika yapımına yansımıştır. Örneğin 2013 yazındaki Gezi Parkı gösterileri ve aynı yılın Aralık ayında dört bakanla ilgili olarak ortaya atılan yolsuzluk iddiaları ile bağlantılı olarak Başbakan Erdoğan'ın “üst akıl” olarak adlandırdığı Batı ve ABD doğrudan suçlanmış, ABD büyükelçisi bu konuda uyarılmıştır. ${ }^{75} \mathrm{Bu}$ yöntemle Türkiye'deki muhalif kesimler de Batı'nın işbirlikçileri gibi sunularak iç siyasette etkisizleştirmeye çalışılmıştır. ${ }^{76}$ Gezi protestocuları ile 17-25 Aralık sürecini takiben ilişkilerin bozulduğu Gülen Hareketi "üst aklın”

69 “Kuzey Irak’la Tarihi Enerji Anlaşması”, Milliyet, 6 Kasım 2013.

70 “Barzani ve Perver Diyarbakır'da”, Hürriyet, 16 Kasım 2013.

71 David Romano, “Iraqi Kurdistan and Turkey: Temporary Marriage”, Middle East Policy, Cilt 22 Say1 1, 2015, s.89-101.

72 Akın Ünver, "İslamcı Söylemde Değişen İran Algısı ve Türk-İran İlişkilerinin Geleceği”, Ortadoğu Analiz, Sayı 52, 2013, s.63-70.

73 Birol Başkan, "Making Sense of Turkey's Foreign Policy: Clashing Identities and Interests", The Muslim World, Cilt 106, No.1, 2016, s.141-154.

74 Gamze Avc1, "The Justice and Development Party and the EU: Political Pragmatism in a Changing Environment", South European Society and Politics, Cilt 16, No.3, 2011, s.409-421.

75 “Erdoğan: Sizi Ülkemizde Tutmaya Mecbur Değiliz”, Hürriyet, 21 Aralık 2013.

76 Tamer Korkmaz, "Sarmaş Dolaş”, Yeni Şafak, 15 Aralık 2013. 
Türkiye'deki piyonları olarak sunulmuştur. ${ }^{77}$ Aynı şekilde, Mısır'daki 2013 askeri darbesi de ABD ile ilişkili gösterilmiş, ABD Suriye'de Türkiye'nin terörist olarak tanımladığı PYD ile ilişkili Kürt grupları ve dolayısı ile terörü kollamakla suçlanmıştır. ${ }^{78}$ Geçmiş yıllarda Türkiye'de daha çok parlamento dışındaki marjinal siyasi partiler tarafından ifade edilen bu tür Batı karşıtı fikirler böylece hükümet seviyesine çıkarılmıştır.

Genel olarak pragmatizmin hâkim olduğu Türkiye-Rusya ilişkileri de ideoloji bazlı dış politika değişiminden etkilenmiştir. Soğuk savaş sonrası dönemde Rusya ile karşılıklı ekonomik çıkarlara dayanan pragmatik bir dış politika yürüten Türkiye'nin bu durumu AKP iktidarları döneminde de değişmemiş, iki ülke arasındaki ticaret hacmi hızla artmış ve Rusya Türk liderlerin sıklıkla ziyaret ettiği ülkelerden biri olmuştur. Türkiye'nin Rusya'ya enerjideki bağımlılığı ve bir çok Türk şirketi için Rusya’nın önemli bir pazar oluşu pragmatik dış politikayı adeta belirlemiştir. ${ }^{79} \mathrm{Ne}$ var ki Rusya’nın 2015 güzünden itibaren Esad rejimini korumak amacıyla Suriye'ye savaş uçakları göndermesi, TürkiyeRusya ilişkilerini sarsmış ve Rusya'ya ait bir savaş uçağının Kasım 2015'de Türk hava sahasını ihlal etmesi üzerine düşürülmesi ilişkilerde krize neden olmuştur. ${ }^{80}$ Geri adım atmayan Türkiye, Rusya'yı Esad karşıtı muhalefeti yok etmeye çalışmakla suçlarken, Rusya da Türkiye'yi IŞi̇D’in de içinde olduğu radikal gruplara destek olmakla suçlamıştır. ${ }^{81}$ Rusya' ya olan enerji bağımlılığı göz önüne alındığında, Türkiye'nin bu konuda 2015 yılı içerisinde geri adım atmaya yanaşmaması Rusya ile ilişkilerindeki geleneksel pragmatizmden uzaklaşıldığını göstermektedir.

Yukarıda genel hatları verilen 2011-2015 arası dönemde AKP hükümeti ideoloji eksenli bir dış politika izlemiştir. İç siyasette kontrolü tamamen sağlayan AKP, uluslararası ortamın kendisine sağladığı boşlukta İslamcı bir dış siyaset izlemeyi tercih etmiştir. Bu durum uluslararası ortamın hükümete daha az seçenek bıraktığı 2007-2011 döneminden farklıdır. 2007-2011 dönemi içerik olarak 1930’lu yıllar dış politikası ile benzerlik göstermektedir. Her iki dönemde de siyasal elit iç siyasette kontrolü sağlamış, fakat uluslararası ortamın sınırlandırmalarından dolayı ideoloji temelli dış politika takip etmekten kaçınmışlardır.

\section{Sonuç}

Bu çalışmada 1930-1939 ile 2011-2015 arası Türk dış politikalarının kısaca analizleri yapılarak, iç ideolojik siyasi dönüşümleri dış politikaya hangi şartlarda yansıdığı gösterilmeye çalışılmıştır. Buna göre iç siyasette rakipleri tarafından yerinden edilme riski az olan hükümetler eğer uluslararası ortam da kendilerine manevra alanı açıyorsa, iç ideolojik dönüşümleri dış politikaya yansıtmaya daha eğilimli olmaktadırlar. Hükümeti iç politika ya da uluslararası ortamdan yalnızca biri sınırlıyorsa bu durumda pragmatizme dayalı aktif bir dış politika izlenmektedir. 1930'lu ve 2010'lu yıllardaki Türk dış politikasının karşılaştırılması bu fikri desteklemektedir.

1930’lu yıllarda karar alıcılar iç siyasette iktidara yönelik tehditleri yok etmişlerse de, uluslararası ortamda ideolojilerine uygun bir dış politika oluşturacak manevra alanından yoksun kalmışlar, yükselen İtalyan ve Alman faşizmi tehlikesi uluslararası ortamda manevra alanını daraltmıştır. $\mathrm{Bu}$

77 Mahmut Övür, “Paralel Yapıya Talimat ‘Üst Akıl'dan”, Sabah, 9 Kasım 2014.

78 Ahmet Topal, "Ankara ile Pentagon Arası PYD Restleşmesi”, Sabah, 17 Ekim 2015.

79 Ziya Öniş ve Şuhnaz Yılmaz, "Turkey and Russia in a Shifting Global Order: Cooperation, Conflict and Asymmetric Interdependence in a Turbulent Region”, Third World Quarterly, Cilt 37 No.1, 2016, s.71-95

80 "Rusya ile Kriz Çıktı, Fiyatlar Tepetaklak", Hürriyet, 3 Aralık 2015.

81 Nerdun Hacıoğlu, “Putin’den Ağır İtham: Türkiye IŞİD Petrolü İçin Vurdu”, Hürriyet, 30 Kasım 2015. 
durumda tamamen ideoloji temelli bir dış politika izlemek zorlaşmış, uluslararası ortam politika seçeneklerini dikte etmiş, karar vericilerin tercihlerini sınırlandırmıştır. Yine de, iç siyasetin rahatlığını arkalarına alan Kemalist elit, Balkanlar, Ortadoğu ve Akdeniz'de Türkiye’nin güvenliğini garantiye alacak ittifakları öncelleyen aktif bir dış politika izlemiştir.

2010'lu yıllarda ise AKP, iç siyasette ordunun vesayetinden kurtulmuş, Türk siyaseti üzerinde egemenliğini kurarak, İslamcılık anlayışını öne çıkarmıştır. ABD’nin Irak'tan çekilmesi ve Arap Baharının getirdiği yeni siyasi dinamikler de Türkiye'ye Ortadoğu'da yeni manevra alanları açmışır. $\mathrm{ABD}$, bölgedeki çıkarları açısından, $\mathrm{AB}$ de Suriyeli mülteciler konusunda Türkiye’ yle çalışmak zorunda olduğundan Türkiye'yi sınırlandıran politika seçeneklerinden çekinmişlerdir. İç ve dış siyasetteki bu yeni şartları kullanan AKP iktidarı da Sünni İslamcılık reflekslerine dayalı ideoloji temelli bir dış politika izlemeye başlamıştır. 2016 yılından itibaren ise, bir taraftan dış ortam giderek Türkiye'yi daha fazla tehdit eder hale gelince, diğer taraftan da içeride hem Mayıs 2016'daki hükümet değişikliği hem de takip eden dönemde 15 Temmuz darbe girişiminin yansımalarının etkisi ile AKP içe yönelik söylemini ve dış politikasını değiştirmeye başlamıştır. 


\section{Kaynakça}

Altınkaş, Evren. "Cumhuriyet'in İlk Yıllarında Aydınlar: Kurucu İdeolojinin Seçkinleri”, Cumhuriyet Tarihi Araştırmaları Dergisi, Cilt 7 No.4, 2011, s.114-132.

Arsan, Nimet (der.). Atatürk’ün Söylev ve Demeçleri, Türk İnkılap Tarihi Enstitüsü, Ankara, 1961.

Avc1, Gamze. “The Justice and Development Party and the EU: Political Pragmatism in a Changing Environment”, South European Society and Politics, Cilt 16, No.3, 2011, s.409-421.

Aydın, Mustafa. "Determinants of Turkish Foreign Policy: Historical Framework and Traditional Inputs," Middle Eastern Studies, Cilt 35 No.4, 1999.

Ayoob, Mohammed. Third World Security Predicament: State-Making, Regional Conflict and the International System, Lynne Rienner, Boulder, CO, 1995.

Barkey, Henri. "Turkey's Turmoil: Why Erdogan and the Kurds are Both to Blame," The National Interest, 25 Eylül 2015.

Barlas, Dilek. "Turkish Diplomacy in the Balkans and the Mediterranean: Opportunities and Limits for MiddlePower Activism in the 1930s", Journal of Contemporary History, Cilt 40 No.3, 2005, s.441-464.

Barnett, Michael. "Culture, Strategy and Foreign Policy Change: Israel's Road to Oslo", European Journal of International Relations, Cilt 5 No.1, 1999, s.5-36.

“Barzani ve Perver Diyarbakır'da”, Hürriyet, 16 Kasım 2013.

Başkan, Birol. "Making Sense of Turkey's Foreign Policy: Clashing Identities and Interests", The Muslim World, Cilt 106, No.1, 2016, s.141-154

Bayramoğlu, Ali. 28 Şubat: Bir Müdahalenin Güncesi, Birey Yayınları, İstanbul, 2001.

Bora, Tanıl. Türk Sağının Üç Hali, İletişim, İstanbul, 1998.

Corke, Susan, Andrew Finkel, David J. Kramer, Carla Anne Robins ve Nate Schenkkan. Democracy in Crisis: Corruption, Media and Power in Turkey, New York, Freedom House, 2014.

Çagaptay, Soner. "Defining Turkish Power: Turkey as a Rising Power Embedded in the Western International System”, Turkish Studies, Cilt 14 No.4, 2013, s.797-811.

Çavdar, Gamze. “Islamist New Thinking in Turkey: A Model for Political Learning?”, Political Science Quarterly, Cilt 121 No.4, 2006, s.477-497.

Dagi, İhsan D. "Transformation of Islamic Political Identity in Turkey: Rethinking West and Westernization”, Turkish Studies, Cilt 6 No.2, 2005, s.21-37.

Deringil, Selim. Turkish Foreign Policy During the Second World War: Active Neutrality, Cambridge University Press, New York, 2004.

“Erdoğan: Derdimiz Mezhepçilik Değil, İslam”, Yeni Akit, 1 Ağustos 2015. "EU Opens Turkey Membership Talks", BBC News, 4 Ekim 2005, http://news.bbc.co.uk/2/hi/europe/4305500.stm.

“Erdoğan: Sizi Ülkemizde Tutmaya Mecbur Değiliz”, Hürriyet, 21 Aralık 2013.

Ertosun, Erkan. Filistin Politikamız: Camp David'den Mavi Marmara'ya, İstanbul, Kaknüs Yayınları, 2014.

Filkins, Dexter. "What We Left Behind”, The New Yorker, 28 Nisan 2014.

Frey, Frederick W. The Turkish Political Elite, MIT Press, Boston, MA, 1965.

Goldstein, Judith and Robert O. Keohane. Ideas and Foreign Policy: Beliefs, Institutions, and Political Change, Cornell University Press, Ithaca, 1993.

Görener, Aylin Ş. ve Meltem Ş. Ucar. "The Personality and Leadership Style of Recep Tayyip Erdoğan: Implications for Turkish Foreign Policy”, Turkish Studies, Cilt 12 No.3, 2011, s.357-81.

Graeber, David. "Turkey Could Cut Off Islamic State’s Supply Lines. So Why Does not It”, Guardian, 18 Kasım 2015. 
Gunter, Michael M. "Iraq, Syria, Isis, and the Kurds: Geostrategic Concerns for the U.S. and Turkey”, Middle East Policy, Cilt 22 No.1, 2015, s.102-111.

Hacıoğlu, Nerdun. "Putin'den Ağır İtham: Türkiye IŞiD Petrolü İçin Vurdu”, Hürriyet, 30 Kasım 2015.

Hale, William. Turkish Foreign Policy since 1774, (3. Baskı), Routledge, Abingdon, 2013.

Holsti, Karl J. "National Role Conceptions in the Study of Foreign Policy," International Studies Quarterly, Cilt 14 No.3 1970, s.233-309.

Hunt, Michael. Ideology and U.S. Foreign Policy, Yale University Press, New Haven, 2009.

Karakoç, Ercan. "Atatürk’ün Hatay Davası”, Bilig, Sayı 50, 2009, s.97-118.

Kayaoglu, Turan. "Getting Turkey Back on Track to Democracy, Human Rights and Religious Freedom”, The Review of Faith and International Affairs, Cilt 14 No.2, 2016, s.14-22.

Kılınç, Ramazan. "Critical Junctures, Catalysts, and Democratic Consolidation in Turkey", Political Science Quarterly, Cilt 129 No.2, 2014, s.293-318.

Kulınç, Ramazan. "International Pressure, Domestic Politics, and the Dynamics of Religious Freedom: Evidence from Turkey”, Comparative Politics, Cilt 46 No.2, 2014, s.127-145.

Kirişçi, Kemal. "The Transformation of Turkish Foreign Policy: The Rise of the Trading State”, New Perspectives on Turkey, Say1 40, 2009, s.29-57.

Koloğlu, Orhan. Mazlum Milletler Devrimleri ve Türk Devrimi, 2. Baskı, Kaynak Yayınları, Ankara, 2004.

Korkmaz, Tamer. "Sarmaş Dolaş”, Yeni Şafak, 15 Aralık 2013.

Kösebalaban, Hasan. Turkish Foreign Policy: Islam, Nationalism, and Globalization, Palgrave Macmillan, New York, 2011.

Kösebalaban, Hasan. “The Crisis in Turkish-Israeli Relations: What is Its Strategic Significance?”, Middle East Policy, Cilt 27 No.3, 2010, s.36-50.

Kuru, Ahmet T. Secularism and State Policies toward Religion: The United States, France, and Turkey, Cambridge University Press, New York, 2009.

Kuru, Ahmet T. “Turkey's Failed Policy toward the Arab Spring: Three Levels of Analysis”, Mediterranean Quarterly, Cilt 26 No.3, 2015, s.94-116.

“Kuzey Irak’la Tarihi Enerji Anlaşması”, Milliyet, 6 Kasım 2013.

Levi, Werner. “Ideology, Interests, and Foreign Policy," International Studies Quarterly, Cilt 14 No.1, 1970.

Macfie, A. L. “The Straits Question: The Conference of Montreux”, Balkan Studies, Cilt 13 No.2, 1972, s.203-219.

Mearsheimer, John J. The Tragedy of Great Power Politics, Norton, New York, 2001.

Moravcsik, Andrew. "A New Statecraft? Supranational Entrepreneurs and International Cooperation", International Organization, Cilt 53 No.2, 1999, s.267-306.

Muadini, Fait. "The Politics between the Justice and Development Party and the Gülen Movement in Turkey: Issues of Human Rights and Rising Authoritarianism," Muslim World Journal of Human Rights, Cilt 12 No.1, 2015, s.99-122.

Mufti, Malik. Daring and Caution in Turkish Strategic Culture: Republic at Sea, Palgrave Macmillan,

London, 2009.

Mufti, Malik. "The Many-Colored Cloak: Evolving Conceptions of Democracy in Islamic Political Thought”, American Journal of Islamic Social Sciences, Cilt 27 No.1, 2010, s.1-27.

Nye, Joseph S. "Redefining the National Interest”, Foreign Affairs, Cilt 78 No.4, 1999, s.22-35.

Onuf, Nicholas. "Institutions, Intentions, and International Relations", Review of International Studies, Cilt 28 No.2, 2002, s.211-228.

Oran, Baskın. Türk Dış Politikası: Kurtuluş Savaşından Bugüne Olgular, Belgeler, Yorumlar, Cilt 1: 1919-1980, İletişim Yayınları, İstanbul, 2001. 
Öniş, Ziya ve Şuhnaz Yllmaz. "Between Europeanization and Euro-Asianism: Foreign Policy Activism in Turkey during the AKP Era”, Turkish Studies, Cilt 10 Sayı 1, 2009, s.7-24.

Öniş, Ziya ve Şuhnaz Yılmaz. "Turkey and Russia in a Shifting Global Order: Cooperation, Conflict and Asymmetric Interdependence in a Turbulent Region", Third World Quarterly, Cilt 37 No.1, 2016, s.71-95

Öniş, Ziya. "Political Islam at the Crossroads: From Hegemony to Co-Existence", Contemporary Politics, Cilt 7 No.3, 2001, s.281-298.

Övür, Mahmut. “Paralel Yapıya Talimat ‘Üst Akıl'dan”, Sabah, 9 Kasım 2014.

Özkan, Behlül. “Turkey, Davutoğlu and the Idea of Pan-Islamism”, Survival, Cilt 56 No.4, Temmuz 2014, s.119-140.

Özkurmll, Umut (der). The Making of a Protest Movement in Turkey: \#Occupy Gezi, Palgrave MacMillan, London, 2014.

Özyürek, Esra. Nostalgia for the Modern: State Secularism and Everyday Politics in Turkey, Duke University Press, Durham, NC, 2006.

Parla, Taha. Ziya Gökalp, Kemalizm ve Türkiye'de Korporatizm, İletişim Yayınları, İstanbul, 1989.

Romano, David. "Iraqi Kurdistan and Turkey: Temporary Marriage", Middle East Policy, Cilt 22 Sayı 1, 2015, s.89-101.

“Rusya ile Kriz Çıktı, Fiyatlar Tepetaklak”, Hürriyet, 3 Aralık 2015.

Samaan, Jean-Loup. "The Rise and Fall of the 'Turkish Model' in the Arab World”, Turkish Policy Quarterly, Cilt 12 No.3, 2013, s.61-69.

Sanger, David E. "Rebel Arms Flow is Said to Benefit Jihadists in Syria”, New York Times, 15 Ekim 2012.

Sanjian, Avedis K. “The Sanjak of Alexandretta (Hatay): Its Impact on Turkish-Syrian Relations, 1939-1956”, Middle East Journal, Cilt 10 No.4, 1956, s.379-94.

Shanzar, Jonathan ve Merve Tahiroğlu. “Ankara's Failure: How Turkey Lost the Arab Spring”, Foreign Affairs, 25 Ocak 2016.

Snyder, Jack. Myths of Empire: Domestic Politics and International Ambition, Cornell University Press, Ithaca, NY, 1991.

Sözen, Ahmet. "A Paradigm Shift in Turkish Foreign Policy: Transition and Challenges," Turkish Studies, Cilt 11 No.1, 2010, s.103-123.

Topal, Ahmet. "Ankara ile Pentagon Arası PYD Restleşmesi”, Sabah, 17 Ekim 2015.

Ünver, Akın. “İslamcı Söylemde Değişen İran Algısı ve Türk-İran İlişkilerinin Geleceği”, Ortadoğu Analiz, Sayı 52, 2013, s.63-70.

Waltz, Kenneth. Theory of International Politics, McGraw Hill, New York, 1979.

Wendt, Alexander. Social Theory of International Politics, Cambridge University Press, New York, 1999.

Yegin, Mehmet. "Turkey's Reaction to the Coup in Egypt in Comparison with the US and Israel”, Journal of Balkan and Near Eastern Studies, Cilt 18 No.4, 2016, s.407-421.

Yllmaz, Hale. Becoming Turkish: Nationalist Reforms and Cultural Negotiations in Early Republican Turkey, 19231945, Syracuse University Press, Syracuse, 2013. 